\title{
Ecological Values of Shallow-Water Habitats: Implications for the Restoration of Disturbed Ecosystems
}

\author{
Cary B. Lopez, ${ }^{1}$ James E. Cloern, ${ }^{1 *}$ Tara S. Schraga, ${ }^{1}$ Amy J. Little, ${ }^{1}$ \\ Lisa V. Lucas, ${ }^{1}$ Janet K. Thompson, ${ }^{1}$ and Jon R. Burau ${ }^{2}$ \\ ${ }^{1}$ US Geological Survey, 345 Middlefield Road MS 496, Menlo Park, California 94025, USA; ${ }^{2}$ US Geological Survey, Placer Hall, \\ 6000 J Street, Sacramento, California 95819, USA
}

\begin{abstract}
A presumed value of shallow-habitat enhanced pelagic productivity derives from the principle that in nutrient-rich aquatic systems phytoplankton growth rate is controlled by light availability, which varies inversely with habitat depth. We measured a set of biological indicators across the gradient of habitat depth within the SacramentoSan Joaquin River Delta (California) to test the hypothesis that plankton biomass, production, and pelagic energy flow also vary systematically with habitat depth. Results showed that phytoplankton biomass and production were only weakly related to phytoplankton growth rates whereas other processes (transport, consumption) were important controls. Distribution of the invasive clam Corbicula fluminea was patchy, and heavily colonized habitats all supported low phytoplankton biomass and production and functioned as food sinks. Surplus primary production in shallow, uncolonized habitats provided potential subsidies to neighboring recipient habitats. Zooplankton in
\end{abstract}

\section{INTRODUCTION}

Motivated by the recognition that human activities operate across landscapes to disrupt biological communities and their supporting functions, we have begun a new era of environmental manage-

Received 3 September 2004; accepted 29 March 2005; published online 13 April 2006.

*Corresponding author; e-mail: jecloern@usgs.gov deeper habitats, where grazing exceeded phytoplankton production, were likely supported by significant fluxes of phytoplankton biomass from connected donor habitats. Our results provide three important lessons for ecosystem science: (a) in the absence of process measurements, derived indices provide valuable information to improve our mechanistic understanding of ecosystem function and to benefit adaptive management strategies; (b) the benefits of some ecosystem functions are displaced by water movements, so the value of individual habitat types can only be revealed through a regional perspective that includes connectedness among habitats; and (c) invasive species can act as overriding controls of habitat function, adding to the uncertainty of management outcomes.

Key words: restoration; shallow-water habitat; pelagic production; food web; freshwater ecosystems. ment at the scale of large ecosystems (Vitousek and others 1997). Symptoms of ecosystem disturbance include the loss of biodiversity and the displacement of indigenous species by aliens. Because these symptoms are often responses to multiple stressors, strategies for ecosystem rehabilitation require multiple actions. One approach is based on the premise that habitat diversity is essential for biological diversity because a mosaic of connected habitats provides the full set of ecological and bio- 
geochemical functions required to sustain complex biological communities (Noss 1983). The costs of rebuilding lost habitat in disturbed ecosystems can be large, and the benefits are highly uncertain because our experience in the practice of ecosystem management through habitat restoration is still limited (Roe and Eeten 2002; Holl and others 2003). Performing studies prior to habitat restoration can reduce this uncertainty by identifying and measuring the ecological functions provided by specific habitat types (Engelhardt and Ritchie 2001; Lucas and others 2002). Here we present the results of such a study, which was designed to measure pelagic functions and assess their ecological value across a range of aquatic habitats in the highly disturbed Sacramento-San Joaquin River Delta.

California's Delta, which is situated at the confluence of two large rivers (Figure la) and was once a $1,400-\mathrm{km}^{2}$ wetland (Atwater and others 1979), receives about $30-\mathrm{km}^{3}$ of annual runoff from a 140,000-km² watershed (Knowles 2002). Between 1860 and 1940, most of the tidal wetlands were drained and transformed into a landscape of diked farm tracts within a network of channels that is now the hub of California's highly managed water supply. This transformation was followed by changes in biological communities at multiple trophic levels, some of which have been documented through monitoring programs sustained over the past four decades (Jassby and others 2002; Kimmerer 2002).

In this study, we measured biomass and calculated productivity of phytoplankton and mesozooplankton across a range of Delta habitats. We were motivated by multiple lines of evidence suggesting that primary and secondary production are low and limit production by native species of fish, including permanent residents (Delta smelt Hypomesus transpacificus, splittail Pogonichthys macrolepidotus) and migratory species (Chinook salmon Oncorhynchus tshawytscha) listed as threatened or endangered (Brown 2003). Previous studies have established that (a) phytoplankton primary production is the most important source of energy fueling production within metazoan food webs, even though the Delta receives large inputs of detritus from river inflow (Sobczak and others 2002); (b) primary production within the Delta is inherently low because of high turbidity and has declined more than 40\% since 1975 (Jassby and others 2002); (c) the growth and reproduction of crustacean zooplankton are limited by low phytoplankton biomass (Müller-Solger and others 2002); and (d) stocks of zooplankton, including copepods, cladocerans, and rotifers, have declined significantly since the 1970s
(Orsi and Mecum 1996). The declining productivity of pelagic food webs has been hypothesized to be a contributing factor to population declines of native fishes (Bennett and Moyle 1996), including species that are the target of a large-scale restoration program (Jacobs and others 2003).

A strategic goal of the CALFED Bay-Delta Ecosystem Restoration Program is to restore natural processes, and one of its objectives to increase productivity to support the recovery of native species (California Bay-Delta Authority 2004). It is presumed that the historic loss of shallow habitat has contributed to the decline in Delta pelagic primary and secondary productivity (CALFED 2000) and that the restoration of shallow habitat may reverse that trend by increasing productivity and rehabilitating food web processes that support higher trophic levels (CALFED 2001). The presumed link between production at the food web base and higher trophic levels is consistent with a cascading set of responses that followed the 1986 introduction of the alien clam Potamocorbula amurensis into the downstream estuary of San Francisco Bay (Nichols and others 1990). Within a year of its introduction, $P$. amurensis dominated macrobenthos biomass in the upper estuary, reaching densities sufficient to remove phytoplankton by filter-feeding faster than the phytoplankton growth rate. Primary production declined fivefold (Alpine and Cloern 1992), and over the following decades, populations of the copepod Eurytemora affinis and mysid shrimp Neomysis mercedis collapsed (Kimmerer and Orsi 1996) and abundances of native fishes declined significantly (Feyrer and others 2003). This carefully documented suite of responses is strong evidence that the disruption of forage production within pelagic/epibenthic food webs can contribute to stock declines of native fishes through forced diet shifts and food limitation. Independent evidence comes from observations that phytoplankton biomass (Schemel and others 2003) and juvenile Chinook salmon growth rates and survival (Sommer and others 2001) are significantly higher in shallow inundated floodplains than in the adjacent deep channel of the Sacramento River.

The presumption that shallow habitats support high pelagic productivity derives from the principle that phytoplankton growth rate varies inversely with habitat depth in nutrient-rich aquatic systems (Petersen and others 2003) and assumes that bottom-up control regulates productivity. High nutrient concentrations are characteristic of the Delta (Jassby and others 2002) and San Francisco Bay, where the phytoplankton growth rate $(\mathrm{P} \mu)$ fits an empirically derived function of irradiance (Cloern 
and others 1985): $\mathrm{P} \mu=-0.09+0.096 \mathrm{E} /(\mathrm{kH})$, where $\mathrm{E}$ is surface irradiance, $\mathrm{k}$ is the light attenuation coefficient, and $\mathrm{H}$ is water column depth. For the characteristic summer values of $\mathrm{E}$ (approximately 40 Einsteins $\left.\mathrm{m}^{-2} \mathrm{~d}^{-1}\right)$ and $\mathrm{k}(2.0$ $\mathrm{m}^{-1}$ ) measured in our study, we can apply this function to specify a depth-scaling hypothesis for the Delta as $\mathrm{P} \mu=-0.09+1.91 / \mathrm{H}$, implying that the water-column phytoplankton growth rate decreases as habitat depth increases and becomes zero at the critical depth of approximately $21.2 \mathrm{~m}$.

Our study was designed around the hypothesis that plankton biomass and production also vary inversely with habitat depth, assuming that bottom-up processes regulate biomass and production at the food web base in this food-limited system. To test this hypothesis, we measured plankton biomass and computed a set of productivity indices across a range of habitat depths within the Delta ecosystem. Observations supporting this hypothesis would provide an objective empirical basis for the expectation that the creation of new shallow habitats will amplify food supply functions in pelagic food webs and promote the recovery of target species. Contradictory observations would demand an understanding of other controlling processes and a reconsideration of the ecosystem benefits to be derived from this restoration strategy.

\section{Site Description And Methods}

\section{Study Site}

The Delta is a complex physical system that transitions from a strictly riverine regime at its landward margin to a tidally oscillating interconnected network of channels and open-water areas at its seaward boundary. Situated at the head of San Francisco Bay, this freshwater ecosystem is subject to numerous physical influences, including primarily semidiurnal tides, river and stream inflow, wind stress, solar radiation, and anthropogenic manipulation of pumps, gates, and barriers. All of these factors influence the physical transport of water, solutes, particles, and suspended biota such as plankton.

\section{Study Design}

We focused our study in and around Franks Tract (FT) and Mildred Island (MI), subsided farm tracts that flooded when their bounding levees were destroyed by large floods in 1938 and 1983, respectively. We sampled 2 sites in FT (surface area, 12.9 $\mathrm{km}^{2}$; mean depth, approximately $\left.2.5 \mathrm{~m}\right), 2$ sites in
MI (surface area, $4.1 \mathrm{~km}^{2}$; mean depth, approximately $5 \mathrm{~m}$ ), and 12 sites in peripheral channels (Figure $1 \mathrm{~b}$ ). The distribution of sampled habitat depths follows the systemwide hypsograph (Figure la inset), spanning the range of depths in the central Delta. Our study focused on shallow aquatic habitats and their adjacent deep channels because CALFED strategic plans emphasize ecosystem restoration through the rehabilitation and creation of a broad range of interconnected habitats (CALFED 2000, Jacobs and others 2003; California Bay-Delta Authority 2004). This study was designed to contrast pelagic functions across a range of habitat depths and provide an empirical basis for anticipating the outcomes of habitat creation through planned restoration actions or the unintended flooding of farm tracts after levee failures caused by future seismic or hydrologic events.

The study was designed to capture diel/tidal variability (sampling in/around MI every 6 h over a $30 \mathrm{~h}$ period on 5-6 September 2001); weekly variability (in/around MI from 23 August to 13 September 2001); and the spring-summer transition (sampling in/around FT every 3 weeks from 10 April to 9 July 2002). Sampling was intensive in spring and summer because these are the seasons when zooplankton are most food limited (MüllerNavarra and others 2004) and the larval stages of fishes are most dependent upon zooplankton forage (Grimaldo and others 2004). Our study assessed plankton production and trophic transfers. Other functions associated with shallow-water habitat, such as the structural functions provided by submerged and emergent vascular plants, have been assessed by other researchers (for example, Grimaldo and others 2004). We sampled only the mesozooplankton because energy supplies from the microbial loop to metazoan food webs are small relative to phytoplankton primary production (Sobczak and others 2002).

\section{Sample Collection and Analyses}

Water samples were collected from 1-1.5 m below the surface using a Van Dorn sampler or peristaltic pump and stored on ice in the dark until processing. Duplicate aliquots were filtered onto GF/F filters, placed on dry ice, and stored at $-80^{\circ} \mathrm{C}$ until analyzed for chlorophyll a concentration ( $\mathrm{Chl} a)$ using a Turner TD700 fluorometer (Parsons and others 1984). Separate aliquots were filtered onto $0.4-\mu \mathrm{m}$ polycarbonate filters and dried for gravimetric determination of suspended particulate matter (SPM) concentration (Hager 1994). We pooled our results with $\mathrm{Chl} a$ and SPM measure- 


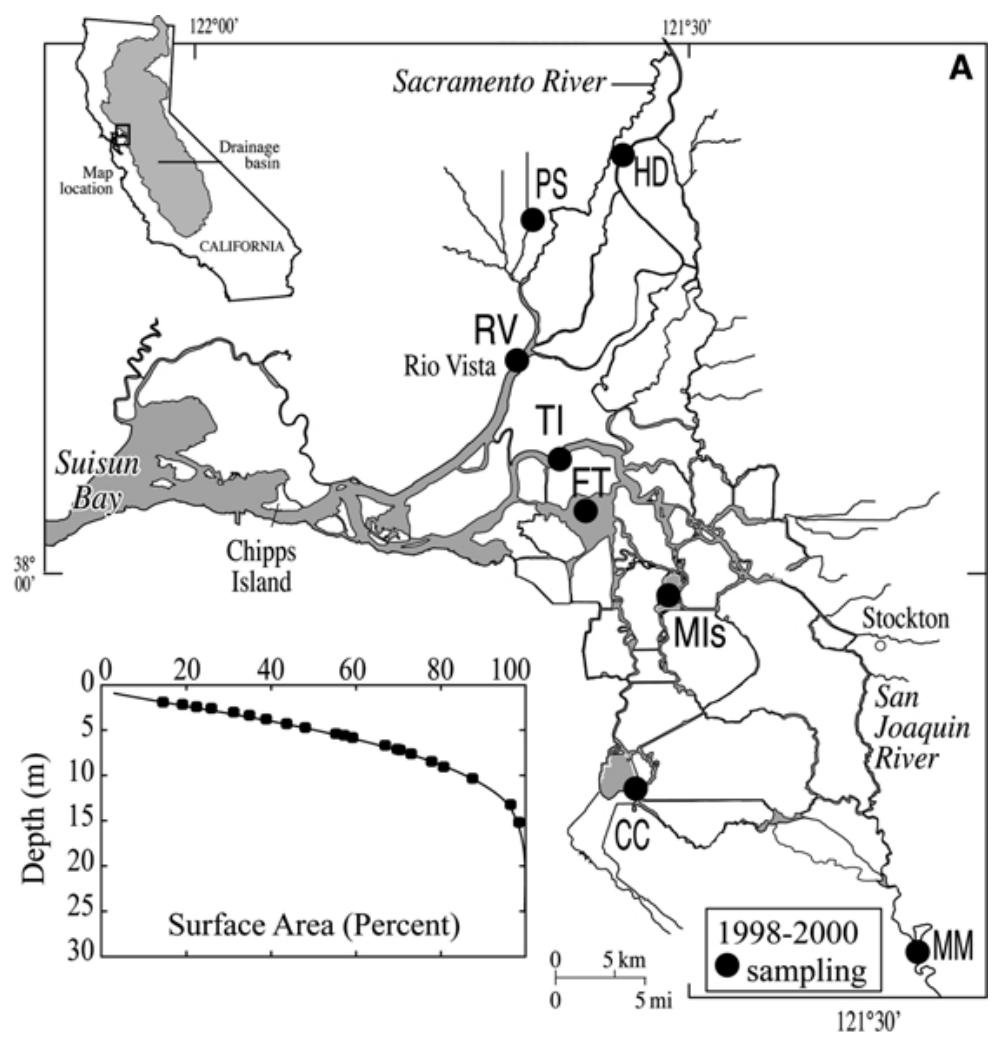

Figure 1. A The Sacramento-San Joaquin Delta, California, showing sites sampled by Sobczak and others (2002) during 1998-2000. (Inset): Central Delta tidally averaged habitat depth distribution by surface area. The hypsograph line shows cumulative percent surface area of the central Delta that is shallower than a given depth; filled circles represent depths of sampling sites in this study. B Enlarged view of the study area showing sites sampled in/around Mildred Island (MI) during 2001 (open triangles) and Franks Tract (FT) during 2002 (open circles).

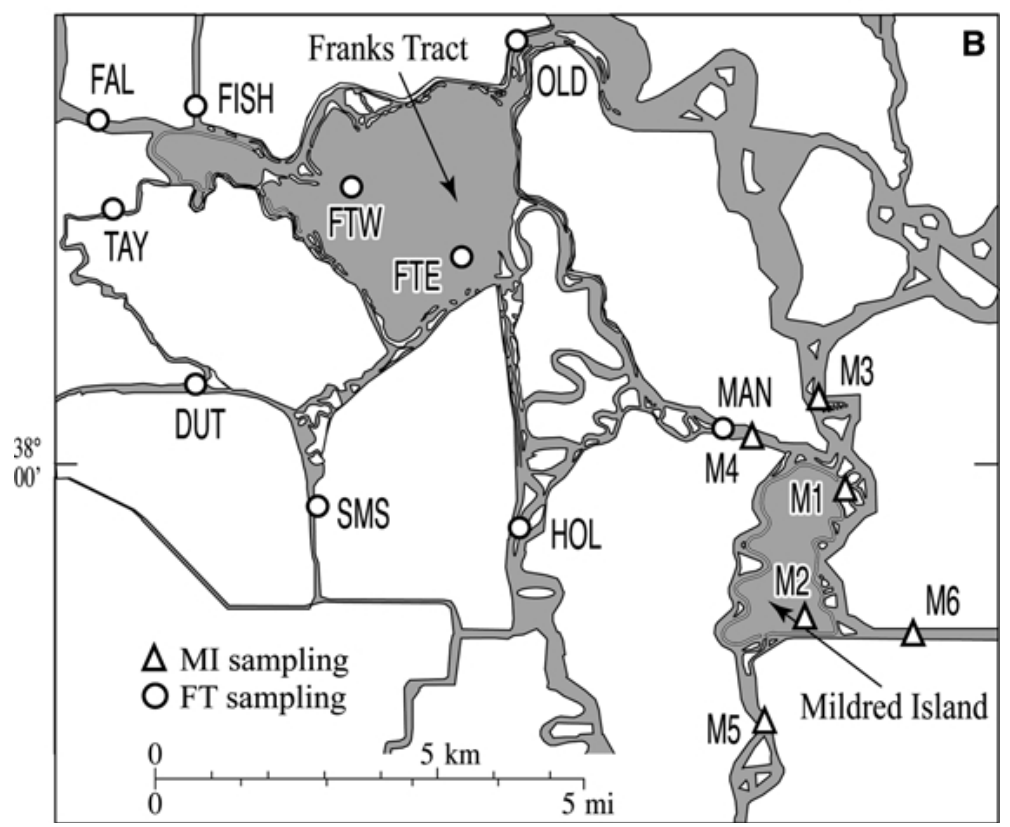

ments made by Sobczak and others (2002) at eight locations (Figure la) during autumn 1998; spring, summer, and autumn 1999; and spring and summer 2000. Phytoplankton samples were collected in/around FT and during the 30-h MI sampling. These samples were preserved in acid-Lugol's solution and examined with a phase-contrast inverted microscope to identify the most common taxa and estimate their biomass (biovolume) from measured cell dimensions (see Cloern and Dufford 2005).

Nutrient samples, collected in/around MI during 2001, were filtered through $0.4-\mu \mathrm{m}$ polycarbonate filters and analyzed for dissolved reactive phosphorus (DRP), dissolved silicate (DSi), nitrate, and nitrite using colorimetric techniques (Parsons and others 1984) with modifications for an Alpkem autoanalyzer. We report these results pooled with 
the results from our previous studies in the central Delta during 1997 (May-November) and 19981999 (seasonally, sites in Figure 1b), when samples were analyzed for dissolved inorganic nitrogen $($ DIN $=$ ammonium + nitrate + nitrite $)$, DRP, and DSi using a Technicon AutoAnalyzer II and methods described by Hager (1994).

Zooplankton samples were collected with a 50$\mu \mathrm{m}$ mesh, $0.5-\mathrm{m}$ diameter net towed vertically or obliquely from the bottom to the surface. Within MI, tows were taken at two or three locations adjacent to the Chl a sampling sites and combined for a composite sample. Zooplankton were preserved in 5\% buffered formalin with Rose Bengal dye. Subsamples were examined in a SedgewickRafter cell, and all rotifers, copepods, and cladocerans were counted and identified to species or genus; lengths of 20 individuals in each category were measured. Copepod nauplii less than 0.20 $\mathrm{mm}$ were considered nonfeeding (N1-2) and not included in grazing-rate computations.

The nonindigenous freshwater clam Corbicula fluminea is a major consumer of phytoplankton biomass in the Delta (Lucas and others 2002), and we collected benthic samples to estimate $C$. fluminea biomass ( $\mathrm{CB}, \mathrm{g}$ ash-free dry weight $\mathrm{m}^{-2}$ ) using a $0.05-\mathrm{m}^{2}$ van Veen grab. Clams retained on a $0.5-$ $\mathrm{mm}$ sieve were preserved in $10 \%$ formalin, followed by $70 \%$ ethyl alcohol. Dry weight of each individual was either measured directly (Crisp 1971) or estimated using length:weight relationships developed for each location and sampling period.

Water temperature was measured with a SeaBird CTD or Hydrolab DS4. The light attenuation coefficient (k) was either measured directly (using a LI-COR LI-192S quantum sensor) or estimated from $\mathrm{Chl} a$ and SPM with the following regression model: $\mathrm{k}=0.76+0.076 \mathrm{SPM}+0.016 \mathrm{Chl} a\left(R^{2}=0.81\right.$, $n=45)$. Daily surface irradiance (E) was measured by the California Irrigation Management Information System (http://www.cimis.water.ca.gov/cimis/ data.jsp). The mean tidal amplitude across the Delta is approximately $1 \mathrm{~m}$, and we assigned tidally averaged depths $\mathrm{H}$ to each sampling site from a 50$\mathrm{m}$ bathymetric grid constructed for a hydrodynamic model and based on the California Department of Water Resources-compiled database of bathymetric surveys by various agencies (Monsen 2001).

\section{Indices of Biomass, Production, and Ecological Efficiency}

We used the results from this sampling program to compute indices of pelagic function as plankton biomass, productivity/trophic transfer, and ecolog- ical efficiencies (Table 1). To enable intercomparisons, all indices were based on carbon $(\mathrm{C})$ as the currency of biomass and energy flow. Phytoplankton biomass, $\mathrm{PB}\left(\mathrm{mg} \mathrm{C} \mathrm{m}^{-3}\right)$, was computed as Chl $a$ multiplied by the mean $\mathrm{C}: \mathrm{Chl} a$ ratio (32

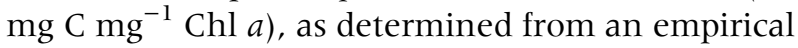
model (Cloern and others 1995) using 220 measurements of water temperature and irradiance across a gradient of Delta habitats from 1998 to 2000 (Sobczak and others 2002). Nutrient regulation of C:Chl a was not considered because dissolved inorganic nitrogen $(\mathrm{N})$, phosphorus $(\mathrm{P})$ and silicon ( $\mathrm{Si}$ ) concentrations are very high and rarely approach levels that limit phytoplankton growth in the Delta (Jassby and others 2002). Zooplankton biomass, $\mathrm{ZB}\left(\mathrm{mg} \mathrm{C} \mathrm{m}^{-3}\right)$, was the cumulative biomass of 45 individual taxa/life stages, computed as the product of abundance $a_{i}$ and carbon biomass $m_{i}$ for each taxon (Table 1). Individual dry weights were estimated from either length measurements and published length-dry weight relationships (for example Sinocalanus doerrii, Dumont and others 1975; Uye 1982), or from published dry weight measurements for specific taxa (for example Hexartha sp, Dumont and others 1975; Bottrell and others 1976). Dry weight was converted to carbon biomass using carbon: dry weight ratios of 0.43 for Eurytemora affinis, 0.38 for Pseudodiaptomus forbesi (C. Hall unpublished), and 0.48 for other taxa (Andersen and Hessen 1991).

Areal gross primary productivity, $\mathrm{Pg}\left(\mathrm{mg} \mathrm{C} \mathrm{m}^{-2}\right.$ $\left.\mathrm{d}^{-1}\right)$, was calculated from Chl $a$ and irradiance using a model $[\mathrm{Pg}=3.36 \mathrm{Chl} a(\mathrm{E} / \mathrm{k})]$ developed from ${ }^{14} \mathrm{C}$ assimilation assays of samples collected seasonally across the Delta (Jassby and others 2002). Net primary productivity was computed as Pg minus phytoplankton respiration rate, as estimated from a model that scales respiration with growth rate (Cloern and others 1995). Net volumetric primary productivity, PP $\left(\mathrm{mg} \mathrm{C} \mathrm{m}{ }^{-3} \mathrm{~d}^{-1}\right)$, is areal primary productivity divided by habitat depth, $\mathrm{H}$. We calculated depth-averaged phytoplankton specific growth rate, $\mathrm{P}_{\mu}\left(\mathrm{d}^{-1}\right)$, as $\ln [(\mathrm{PP} \Delta t+\mathrm{PB}) / \mathrm{PB}]$, where $\Delta t=1$ day. This procedure is valid for well-mixed water columns with vertically-homogeneous phytoplankton biomass. Profiles of temperature, conductivity, and fluorescence revealed vertical homogeneity or ephemeral stratification that typically disappeared in less than half a day.

We estimated zooplankton community grazing rate, $\mathrm{ZG}\left(\mathrm{mg} \mathrm{C} \mathrm{m} \mathrm{m}^{-3} \mathrm{~d}^{-1}\right)$, from an Ivlev function describing ingestion rate as a hyperbolic function of phytoplankton biomass, where ingestion rate approaches a maximum at $\mathrm{PB}$ approximately equal to $300 \mathrm{mg} \mathrm{C} \mathrm{m}^{-3}$. The ingestion rate, $\mathrm{I}_{i}\left(\mathrm{mg} \mathrm{C} \mathrm{d}^{-1}\right)$, of 


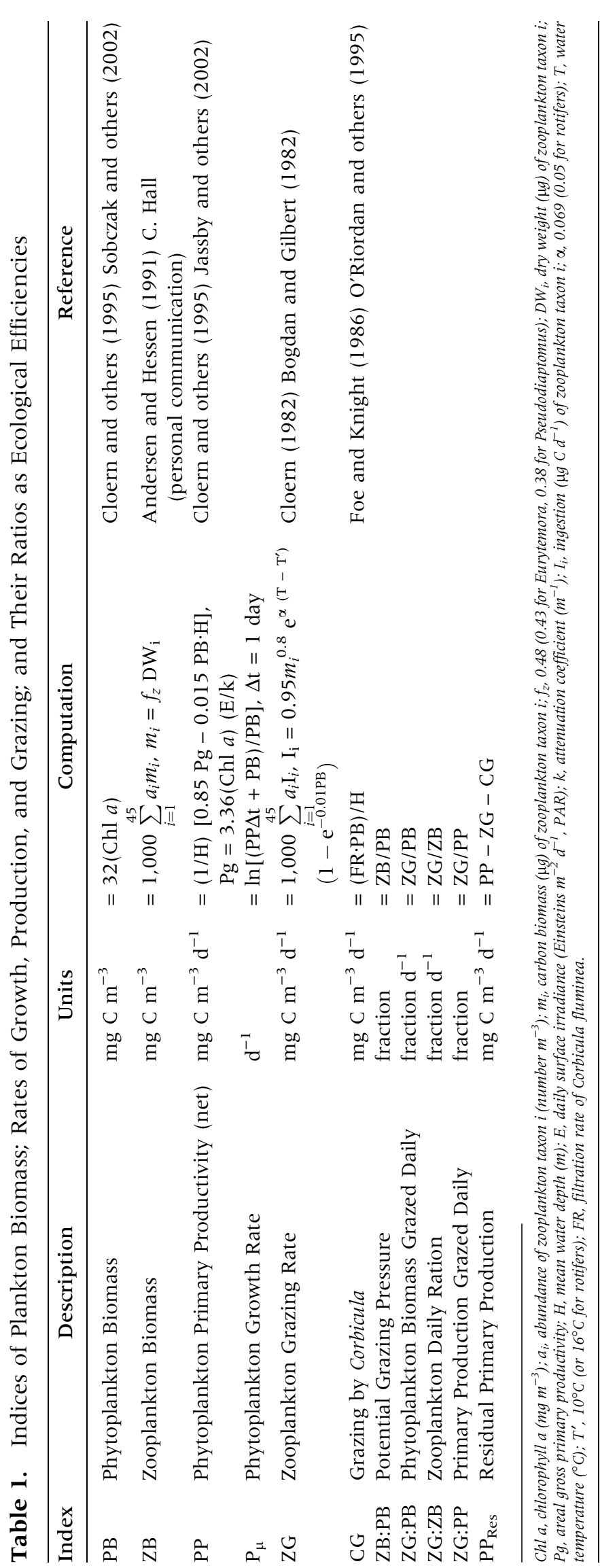

each taxon was computed as a function of phytoplankton biomass $(\mathrm{PB})$, temperature $(\mathrm{T})$, and body size $\left(m_{i}\right)$ to account for size dependency of daily ration (Cloern 1982): $\mathrm{I}_{i}=0.95 m_{i}^{0.8} \quad \mathrm{e}^{\alpha\left(\mathrm{T}-\mathrm{T}^{\prime}\right)}$ $\left(1-\mathrm{e}^{-0.01 \mathrm{~PB}}\right)$, where $\alpha=0.069$ and $\mathrm{T}^{\prime}=10^{\circ} \mathrm{C}$ for all taxa except rotifers $\left(\alpha=0.05\right.$ and $\left.\mathrm{T}^{\prime}=16^{\circ} \mathrm{C}\right)(\mathrm{Bog}$ dan and Gilbert 1982). This ingestion model is based on laboratory determinations of calanoid copepod feeding on phytoplankton in culture (for example, see Harris and Paffenhöfer 1976; Mullin and Brooks 1967) and may not accurately represent feeding by other taxa. However, calanoid copepods were found to contribute $63 \%$ of the cumulative biomass in all zooplankton samples (see below). Estimated grazing by rotifers, which contributed $31 \%$ of the cumulative biomass, was comparable to the lower end of direct measurements (for example, see Starkweather 1980).

We estimated Corbicula fluminea pumping rate, PR [ml (mg dry tissue $\left.\mathrm{wt})^{-1} \mathrm{~h}^{-1}\right]$, using data published by Foe and Knight (1986) of siphon pumping rate PR and clam size as ash-free dry weight. Adjustments were made for water temperature, using a factor $\left(0.43 \mathrm{e}^{0.11 \mathrm{~T}}\right)$ based on laboratory experiments of Foe and Knight (1986). Clam filtration (and phytoplankton ingestion) rates are smaller than pumping rates because of inefficiencies caused by algal depletion in near-bed concentration boundary layers; we computed filtration rates, FR $\left[\mathrm{m}^{3} \mathrm{~m}^{-2} \mathrm{~d}^{-1}\right]$, with the relationship derived by O'Riordan and others (1995), assuming maximum rates of water refiltration (that is, the approach estimates lower bounds on FR). From filtration rates, we calculated water column turnover rate $\left(=\mathrm{FR} / \mathrm{H}, \mathrm{d}^{-1}\right)$ and Corbicula grazing rates $\left(\mathrm{CG}=(\mathrm{FR} \cdot \mathrm{PB}) / \mathrm{H}, \mathrm{mg} \mathrm{C} \mathrm{m} \mathrm{m}^{-3} \mathrm{~d}^{-1}\right.$, Tablel $)$. We classified habitats sampled during our study as "colonized" by Corbicula where CB exceeded $10 \mathrm{~g}$ $\mathrm{dw} \mathrm{m}^{-2}$. We determined occurrences (presence/ absence) of Corbicula at other sampling locations from benthos surveys during 1998-2000 by the California Department of Water Resources (http:// www.iep.ca.gov/data.html) and 2003 (F. Parchaso, personal communication).

\section{High-resolution Spatial Mapping}

During the September 2001 tidal cycle study of MI, we sampled continuously along horizontal transects to measure small-scale variability of phytoplankton biomass and SPM. Separate boats mapped water depth, Chl a fluorescence, and turbidity along transects inside MI and in surrounding channels during five consecutive slack tides. Water was pumped from $1.5 \mathrm{~m}$ to a Turner Designs 10-AU 
fluorometer calibrated with $\mathrm{Chl}$ a samples and a Turner Designs 10-AU nephelometer calibrated with SPM samples. Fathometer depth, fluorescence, and turbidity were measured and stored on a data logger every $5 \mathrm{~s}$, yielding over 24,000 data points, which were then binned into 1-min intervals. We computed primary productivity from $\mathrm{Chl} a$ and SPM at each transect location using the method described above and then estimated total daily primary production inside MI as the mean of all derived PP measurements along the interior transect.

\section{Tidal Transport of Phytoplankton Biomass}

Tidally driven advective and dispersive transport of phytoplankton biomass was measured using an RDI Instruments Acoustic Doppler Current Profiler (ADCP) and near-surface and near-bottom fluorometers (Turner Designs SCUFAs) moored in the opening between Mildred Island and its bounding channel (site Ml, Figure lb). The ADCP measured velocity profiles (binned into $0.5-\mathrm{m}$ depth intervals), and the fluorometers measured fluorescence (calibrated with weekly Chl a samples) every 10 min for 40 days during August-September 2001. Velocity was converted to total discharge (water mass flux, $\mathrm{Q}, \mathrm{m}^{3} \mathrm{~s}^{-1}$ ) through the flow cross section using the rating process of Ruhl and Simpson (2005). Time series of discharge and Chl $a$ (mean of near-surface and near-bottom measurements) were used to compute phytoplankton biomass transport as Chl a flux through the opening. Following Fischer and others (1979), we decomposed the total tidally averaged $\mathrm{Chl} a$ flux into two components: an essentially unidirectional background "advective" flux and a "dispersive" component resulting from ebb/flood differences in $\mathrm{Chl}$ a concentrations:

$$
\langle\dot{C}(t)\rangle=\underbrace{\langle Q(t)\rangle\langle C(t)\rangle}_{\text {advective }}+\underbrace{\left\langle Q^{\prime}(t) C^{\prime}(t)\right\rangle}_{\text {dispersive }}
$$

where \langle\rangle represents the tidal average (computed using a digital filter) (Walters and Heston 1982), $\dot{C}$ represents $\mathrm{Chl} a$ flux $\left(\mathrm{mg} \mathrm{s}^{-1}\right), t$ is time, and 'represents the time-varying fluctuation about the tidal mean.

\section{RESUltS}

\section{Nutrients}

Dissolved inorganic nutrients did not approach concentrations that limit phytoplankton growth in any of the more than 200 samples we collected during 1997-1999 and 2001. Dissolved reactive phosphorus concentrations averaged $2.3 \mu \mathrm{M}$ and were never lower than $0.5 \mu \mathrm{M}$ (Figure 2a). Dissolved inorganic nitrogen averaged $34 \mu \mathrm{M}$ and never fell below $3 \mu \mathrm{M}$ (Figure $2 \mathrm{~b}$ ). Dissolved silica concentrations were never below $130 \mu \mathrm{M}$ (data not shown). These results are consistent with monitoring data collected across the Delta from 1968 to 1998 (Jassby and others 2002) showing that potential nutrient limitation was extremely rare (DIN, DRP) or nonexistent (DSi) and with our assumptions that phytoplankton growth rate in the Delta is limited by light availability and not nutrient resources.

\section{Phytoplankton}

Phytoplankton growth rates ranged from 0.15 to $0.21 \mathrm{~d}^{-1}\left(=0.2\right.$ to 0.3 doublings $\left.\mathrm{d}^{-1}\right)$ at the deepest site and 0.55 to $0.93 \mathrm{~d}^{-1}$ (=0.8 to 1.4 doublings $\mathrm{d}^{-1}$ ) at the shallowest sites. This variability was highly correlated with habitat depth: $\mathrm{P} \mu=0.86-0.27$ $\ln [\mathrm{H}],\left(R^{2}=0.72\right)$, (Figure 3a). If, as hypothesized, phytoplankton biomass is regulated primarily by growth rate, then $\mathrm{PB}$ should vary similarly with $\mathrm{H}$. Over 2,000 measurements of $\mathrm{Chl} a$ within and around MI showed a complex, nonmonotonic relationship between phytoplankton biomass and habitat depth, with highest biomass occurring where $\mathrm{H}$ was approximately 3.5-5.5 m. However, Chl $a$ was extremely variable among subhabitats within that narrow depth range (Figure $3 b$ ). Discrete sampling throughout the Delta over several years also showed that variability of PB (from 40 to $3,500 \mathrm{mg} \mathrm{C} \mathrm{m}^{-3}$ ) was irregular along the habitat depth gradient (Figure 4a) and unrelated to growth rate $\mathrm{P} \mu\left(R^{2}<0.01\right)$. High phytoplankton biomass was common at only three of 24 sampling locations, MM in the lower San Joaquin River and MIs and M2 in Mildred Island (Figure 1). Net primary production ranged from 4 to $1,200 \mathrm{mg} \mathrm{C} \mathrm{m}^{-3} \mathrm{~d}^{-1}$, but this variability was also weakly related to depth of the water column $\left(R^{2}=0.12\right)$ or $\mathrm{P} \mu\left(R^{2}=0.04\right)$ (Figure $4 \mathrm{~b}$ ). This robust data set leads to rejection of our hypothesis that phytoplankton biomass varies systematically across gradients of habitat depth.

The phytoplankton community was dominated by a few taxa, including centric diatoms (Cyclotella spp., Actinocyclus normanii, Skeletonema potamos), cryptophytes (Plagioselmis sp., Teleaulax amphioxeia), Cyanobium sp., Nannochloropsis sp., and smaller components from other divisions (Table 2). Diatoms and cryptophytes have higher nutritional value than other algal taxa, partly be- 


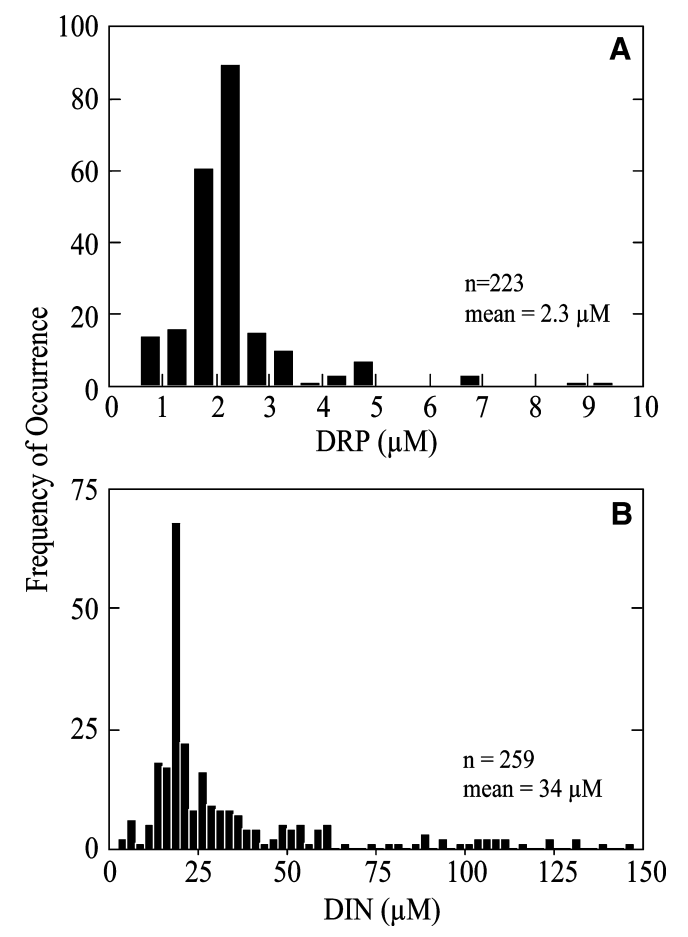

Figure 2. Frequency distributions of $\mathbf{A}$ dissolved reactive phosphorus (DRP) and B dissolved inorganic nitrogen (DIN) concentrations $(\mu \mathrm{M})$ in the Delta during 1997-99 and 2001. Samples from 1997-99 were collected throughout the Delta (including our study area). Samples from 2001 were collected in/around MI during August and September. The number of samples and mean concentrations for the entire sampling period for each constituent are also shown.

cause of their enrichment in essential fatty acids (see, for example, Brett and others 2000). Their large contributions (diatoms $53 \%$ and cryptophytes $25 \%$ ) to cumulative biomass in all samples and the small contributions from cyanobacteria indicate that phytoplankton biomass is an accessible, high-quality food resource for consumers in the Delta.

\section{Zooplankton}

Zooplankton biomass was also dominated by a few taxa, primarily the calanoid copepods Pseudodiaptomus forbesi and Sinocalanous doerri (Table 3). The cumulative biomass of all copepod life stages contributed $49 \%$ of zooplankton biomass in/around MI and $80 \%$ of biomass in/around FT. Rotifers (for example, Hexarthra sp., Brachionus sp., Filinia sp.) contributed $49 \%$ of zooplankton biomass in MI but only $8 \%$ in FT. Cladocerans (Diaphanosoma brachyurum, Bosmina longirostris, Daphnia sp.) were minor components in MI and contributed $11 \%$ of biomass in FT.

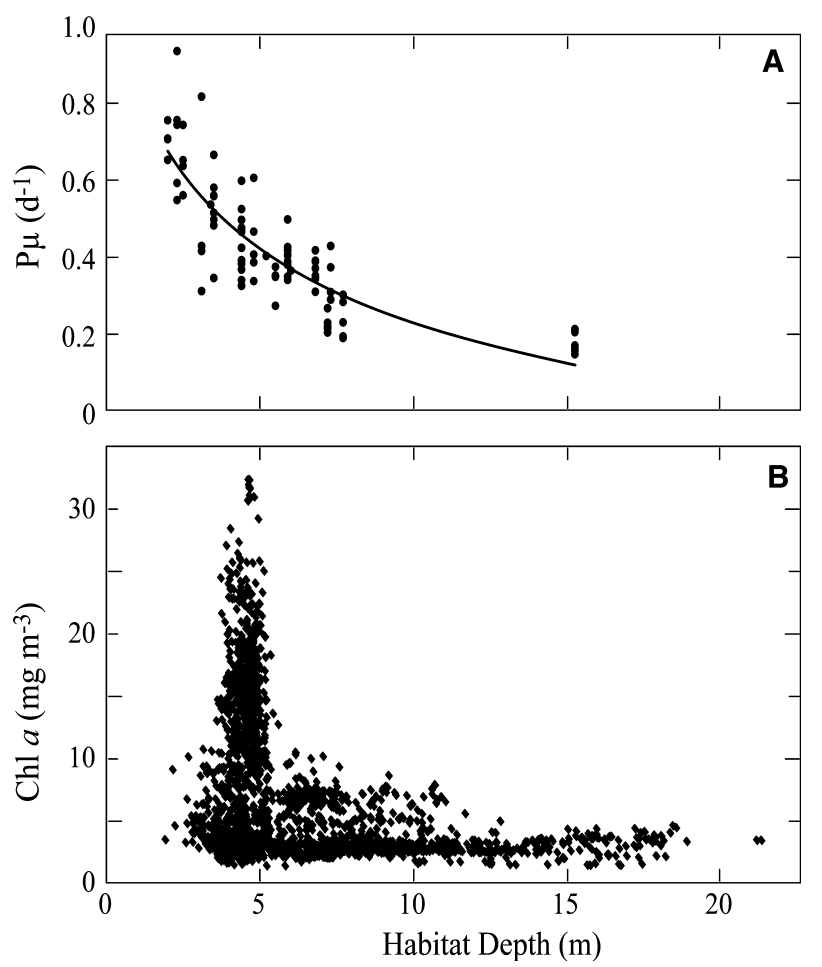

Figure 3. A Phytoplankton growth rate $(\mathrm{P} \mu)$ versus mean habitat depth. Growth rate was calculated from measured temperature, irradiance, and light attenuation in MI during 2001 and in Franks Tract (FT) during 2002. The logarithmic function was fit by least-squares regression: $\mathrm{P} \mu=0.86-0.27 \ln [\mathrm{H}]\left(R^{2}=0.72\right)$. B Chlorophyll $a$ (Chl a) concentrations measured during synoptic mapping plotted against habitat depth. Mapping was performed on five consecutive slack tides within and around MI on 5-6 September 2001.

We hypothesized that zooplankton biomass would covary with phytoplankton biomass because zooplankton are food limited in many Delta habitats. Zooplankton biomass ranged from 4 to $55 \mathrm{mg} \mathrm{C}$ $\mathrm{m}^{-3}$ and was uncorrelated $\left(R^{2}=0.01\right)$ with phytoplankton biomass (Figure 5a) or habitat depth. Estimated rates of zooplankton community grazing were similarly variable, ranging from 5 to $87 \mathrm{mg} \mathrm{C}$ $\mathrm{m}^{-3} \mathrm{~d}^{-1}$. We used two indices to explore the apparent decoupling between phytoplankton and zooplankton biomass. The ratio ZB:PB, which measures the proportion of consumer to producer biomass, was highly variable $(0.03$ to 0.63$)$ where phytoplankton biomass was low, but ZB:PB was always less than 0.1 where $\mathrm{PB}$ exceeded approximately 200 $\mathrm{mg} \mathrm{C} \mathrm{m}{ }^{-3}$ (Figure $5 \mathrm{~b}$ ). The ratio ZG:ZB measures the mean daily ration (ingestion rate as a proportion of biomass) of zooplankton, and this index was also stable (around 2.3) in high-PB habitats and variable (0.7-2.2) in low-PB habitats (Figure 5c). A third 
Table 2. Phytoplankton Community Composition and Percent Biovolume by Species in Mildred Island and Franks Tract and by Taxonomic Division for All samples

\begin{tabular}{cll}
\hline Percent of Total Biovolume & \multicolumn{1}{c}{ Division } & Genus Species \\
\hline Mildred Island & Bacillariophyta & \\
39 & Cryptophyta & Cyclotella atomus \\
15 & Cyanophyta & Plagioselmis sp. \\
13 & Eustigmatophyta & Cyanobium sp. \\
10 & Cryptophyta & Nannochloropsis sp. \\
7 & Bacillariophyta & Teleaulax amphioxeia \\
6 & Chlorophyta & Skeletonema potamos \\
3 & Cyanophyta & Choricystis sp. \\
1 & & Aphanothece sp. \\
Franks Tract & Bacillariophyta & \\
17 & Bacillariophyta & \\
15 & Bacillariophyta & Actinocyclus normanii \\
7 & Cryptophyta & Cyclotella striata \\
3 & Bacillariophyta & Cyclotella atomus \\
3 & Bacillariophyta & Teleaulax amphioxeia \\
3 & Bacillariophyta & Melosira varians \\
2 & Bacillariophyta & Skeletonema potamos \\
2 & Bacillariophyta & Aulacoseira granulata \\
2 & & Cyclotella meneghiniana \\
All samples & Aulacoseira islandica \\
53 & Bacillariophyta & \\
25 & Cryptophyta & \\
9 & Eustigmatophyta & \\
3 & Cyanophyta & \\
2 & Chlorophyta & \\
\hline Only species that made up more than $1 \%$ of total biovolume are listed. & \\
\hline
\end{tabular}

ratio (ZG:PB, not shown) revealed that zooplankton consumed less than $20 \%$ of the phytoplankton standing stock daily at most stations, even where PB was less than the presumed food-saturation algal biomass of $300 \mathrm{mg} \mathrm{C} \mathrm{m}^{-3}$.

\section{Corbicula fluminea Biomass and Grazing Rate}

The distribution of Corbicula fluminea was highly patchy, and its biomass ranged from 0 to $130 \mathrm{~g} \mathrm{dw}$ $\mathrm{m}^{-2}$. Overall, 14 of 23 sites were colonized by Corbiculaj, CB exceeded $10 \mathrm{~g} \mathrm{dw} \mathrm{m}^{-2}$ at 9 sites in/ around FT and MI. Water-column turnover rates by Corbicula filtration ranged from 0.3 to $2.2 \mathrm{~d}^{-1}$ (filtering the overlying water column 0.4 to 3.2 times daily), and Corbicula grazing rates ranged from 20 to $510 \mathrm{mg} \mathrm{C} \mathrm{m}^{-3}$ at the colonized sites. Five of the eight sites from the 1998-2000 sampling were considered to be colonized by Corbicula based on occurrences recorded during benthos surveys in 2003 (F. Parchaso, personal communication) and
1998-2000 (California Department of Water Resources).

\section{Production-Consumption Balances}

We used biomass measures and rate estimates to compute two indices of the balance between primary production and consumption. First, the ratio ZG:PP measures the fraction of daily primary production grazed by mesozooplankton. Although ZG and PP did not vary systematically across habitat types, this ratio was significantly and positively correlated with habitat depth $(y=-0.23+0.12 x$, $R^{2}=0.56$ ) (Figure 6a). At habitat depths less than $8 \mathrm{~m}, \mathrm{ZG}: \mathrm{PP}$ was usually less than $\mathrm{l}$; but at the deepest habitat, ZG:PP usually exceeded 1 (daily zooplankton consumption exceeded phytoplankton production).

A second index was developed from a simple daily budget of phytoplankton biomass: $\mathrm{PP}_{\text {Res }}=\mathrm{PP}$ $+\triangle \mathrm{PB}-\mathrm{ZG}-\mathrm{CG}$, where $\Delta \mathrm{PB}$ is the daily increment of phytoplankton biomass in a water parcel and 
Table 3. Zooplankton Community Composition and Percent Biomass for Mildred Island, Franks Tract, and All Samples Combined

\begin{tabular}{|c|c|c|c|c|c|}
\hline Division & $\%$ & Division & $\%$ & Division & $\%$ \\
\hline \multicolumn{6}{|l|}{ Mildred Island } \\
\hline Copepods & 49 & Herbivorous Rotifers & 49 & Cladocerans & 2 \\
\hline Pseudodiaptomus forbesi & 36.4 & Hexarthra sp. & 17.4 & Diaphanosoma brachyurum & 1.6 \\
\hline Nauplii & 5.2 & Unidentifed & 11.0 & Bosmina longirostris & 0.6 \\
\hline Limnoithona tetraspina & 3.1 & Brachionus sp. & 8.1 & Other species & $<0.5$ \\
\hline Sinocalanus doerrii & 2.1 & Filinia sp. & 4.7 & & \\
\hline Acanthocyclops vernalis & 1.4 & Monostyla sp. & 1.9 & & \\
\hline \multirow[t]{6}{*}{ Eurytemora affinis } & $<0.5$ & Synchaeta bicornis & 1.8 & & \\
\hline & & Polyarthra sp. & 1.3 & & \\
\hline & & Synchaeta sp. & 1.3 & & \\
\hline & & Keratella sp. & 0.9 & & \\
\hline & & Rotaria sp. & 0.7 & & \\
\hline & & Other species & $<0.5$ & & \\
\hline \multicolumn{6}{|l|}{ Franks Tract } \\
\hline Copepods & 80 & Herbivorous Rotifers & 8 & Cladocerans & 11 \\
\hline Sinocalanus doerrii & 35.6 & Unidentified & 7.0 & Bosmina longirostris & 4.9 \\
\hline Pseudodiaptomus forbesi & 29.0 & Other species & $<0.5$ & Daphnia spp. & 2.6 \\
\hline Nauplii & 11.3 & & & Graptolaberis sp. & 1.4 \\
\hline Eurytemora affinis & 2.2 & & & Diaphanosoma brachyurum & 0.9 \\
\hline Acanthocyclops vernalis & 1.7 & & & Unidentified & 0.7 \\
\hline Limnoithona tetraspina & 0.6 & & & Other species & $<0.5$ \\
\hline \multicolumn{6}{|l|}{ All samples } \\
\hline Copepods & 63 & Herbivorous Rotifers & 31 & Cladocerans & 6 \\
\hline
\end{tabular}

$\mathrm{PP}_{\mathrm{Res}}$ is a residual term representing the balance between all processes. If daily changes in biomass, $\triangle \mathrm{PB}$, are small, (Figure $8 \mathrm{~b}$ ), we can assume steady state and estimate the residual term as $\mathrm{PP}_{\text {Res }}=\mathrm{PP}-\mathrm{ZG}-\mathrm{CG}$. The residual $\mathrm{PP}_{\text {Res }}$ was positive and highly correlated with PP where Corbicula was absent $\left(R^{2}=0.99\right)$, but it was small or negative and uncorrelated with PP where Corbicula was abundant (Figure 7a). The daily phytoplankton balance was uncorrelated with zooplankton grazing, regardless of Corbicula presence (Figure $7 \mathrm{~b}$ ). The residual $\mathrm{PP}_{\text {Res }}$ was generally negative and highly correlated with Corbicula grazing where the clam was present $\left(R^{2}=0.77\right.$, Figure $\left.7 \mathrm{c}\right)$.

\section{Tidal Transport}

A 40-day series of current measurements illustrates the strongly tidal nature of water flow between northern MI at its adjacent channel. Volumetric flow rate during August-September 2001 (Figure 8a) oscillated approximately twice daily, with maximum instantaneous flow rates of $200-400 \mathrm{~m}^{3}$ $\mathrm{s}^{-1}$. Chl a concentration was also periodic (Figure $8 \mathrm{~b}$ ), containing a combination of diurnal and semidiurnal frequencies of variability (L. V. Lucas and others unpublished). Superimposed on an ambient advective flux of $\mathrm{Chl} a$ through the Delta system was a dispersive flux of Chl $a$ (Figure 8c) caused by tidal time-scale pumping of higher $\mathrm{Chl} a$ water from MI to the channel. On average, this dispersive flux $\left(<\mathrm{Q}^{\prime} \mathrm{Chl} a^{\prime}>\right)$ was oriented out of MI, meaning that phytoplankton biomass transported to the channel on northerly-flowing ebb tides did not all return on the subsequent flood tide. The mean daily dispersive flux through this opening between MI and the surrounding channel was $1.9 \mathrm{~kg} \mathrm{Chl} a$ $\mathrm{d}^{-1}\left(60.8 \mathrm{~kg} \mathrm{C} \mathrm{d}^{-1}\right)$. The coupled transport of zooplankton is also likely to be important but we have insufficient data to assess zooplankton transport.

\section{Discussion}

\section{What Processes Control Phytoplankton Biomass in a Nutrient-rich Ecosystem?}

Our study began with the hypothesis that shallow aquatic habitats sustain high phytoplankton biomass (and therefore high secondary production) because algal growth is light limited and mean water-column irradiance scales inversely with habitat depth. Estimated growth rates did vary 
systematically across gradients of habitat depth, with highest growth rates in shallow domains (Figure 3a). Shallow, nutrient-rich habitats sustain fast phytoplankton population growth, with maximal rates comparable to 1.4 doublings of biomass per day. However, shallow habitats do not necessarily sustain high algal biomass, and our initial hypothesis was rejected on the basis of high-resolution mapping (Figure $3 \mathrm{~b}$ ) and discrete sampling across the Delta over several years (Figure 4a). Rejection of the hypothesis motivates consideration of other processes that regulate phytoplankton biomass beyond growth rate, such as top-down regulation by zooplankton and Corbicula and tidally-driven transport processes.

Top-down Processes. Our results indicate that zooplankton grazing is not fast enough to control phytoplankton biomass in most habitats. Median ZG was only $40 \%$ of median PP, and the ratio ZG:PP shows that net production usually exceeds depth-integrated zooplankton grazing in habitats shallower than $8 \mathrm{~m}$ (Figure 6a). The significant linear relation in Figure 6a (which remains significant with a similar slope and intercept upon removal of the deepest station, Ml) implies that the pelagic component of shallow habitats functions as a (large) net source of algal biomass. However, deep pelagic systems are net consumers of primary production because algal respiration consumes a large fraction of photosynthetic production in the deep aphotic zone, leaving a small residual insufficient to meet the zooplankton grazing demand.

Phytoplankton biomass and production were consistently low in habitats colonized by Corbicula fluminea (Figure 4). Corbicula grazing rates were, on average, eight times higher than zooplankton grazing rates in those colonized habitats. The residual production $\mathrm{PP}_{\mathrm{Res}}$ provides an index for measuring the effect of Corbicula grazing. Whereas shallow pelagic systems routinely functioned as net sources of phytoplankton biomass (Figure 6a), this trend was not true when we accounted for losses to Corbicula grazing (Figure 6b). Despite higher phytoplankton growth rates in shallow habitats, consumption by Corbicula rendered nearly all colonized shallow habitats phytoplankton sinks $\left(\mathrm{PP}_{\text {Res }}<0\right)$, (Figure $6 \mathrm{~b}$ ). Residual production $\mathrm{PP}_{\mathrm{Res}}$ was regulated by Corbicula grazing at colonized sites, indicating strong top-down control (Figure 7c); however, $\mathrm{PP}_{\text {Res }}$ was highly correlated with primary production at uncolonized sites, indicating bottomup control of biomass (Figure 7a). The power of Corbicula grazing as a control on phytoplankton biomass accumulation in Delta habitats is consistent with the proposition that turbulent,
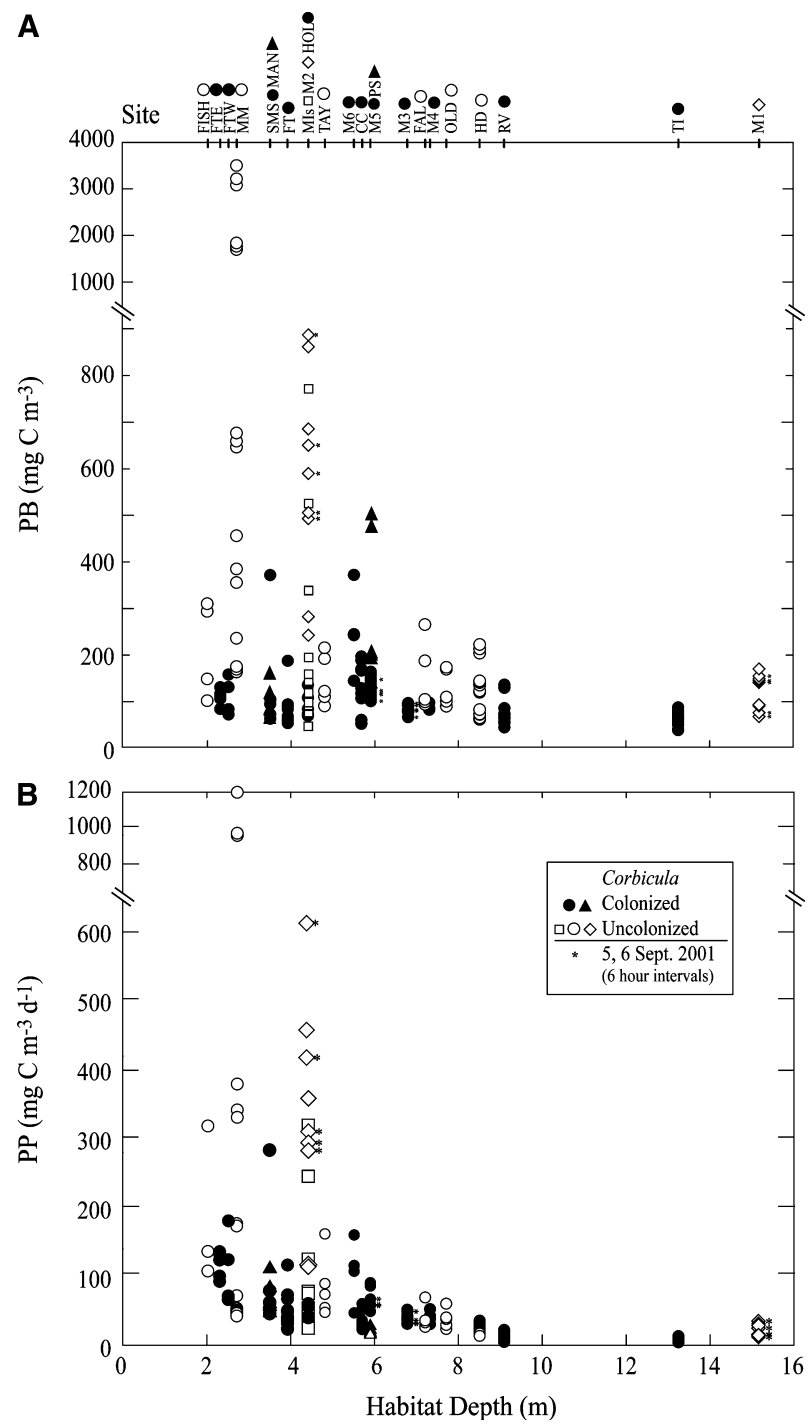

Figure 4. A Phytoplankton biomass (PB). B Net primary production (PP) versus mean habitat depth. Samples were collected during 1998-2000 (Sobczak and others 2002), 2001 (MI) and 2002 (FT). Open symbols indicate stations where Corbicula was rare or absent ("uncolonized"). Filled symbols indicate stations where Corbicula was abundant ("colonized"). Asterisks next to symbols indicate samples taken every $6 \mathrm{~h}$ over $30 \mathrm{~h}$ on 5-6 September 2001. Stations and corresponding symbols are detailed on the top $x$-axis at appropriate depths; stations with common depths are distinguished by different symbols.

light-limited systems are susceptible to declines in primary production due to invasive bivalves (Caraco and others 1997). Our results show that Corbicula colonization will determine a habitat's value to the pelagic food web, supporting the idea that top-down controls can have stronger ecosystem-level effects than bottom-up controls in aquatic systems (Moulton 1999). 
Export from Shallow to Deep Habitats. Transport by advection and tidal dispersion must be an important process in the Delta because some habitats are net producers and others are net consumers of phytoplankton biomass (Figure 6). In the absence of transport, biomass would build in the producing habitats and become depleted in the consuming habitats. Some shallow sites uncolonized by Corbicula (FISH, TAY) failed to support elevated (>320 $\mathrm{mg} \mathrm{C} \mathrm{m}^{-3}$ ) phytoplankton biomass (Figure 4), suggesting that biomass is transported away from productive habitats faster than it can accumulate. Lucas and others (2002) attributed low Chl a concentrations in northern MI to vigorous tidal exchange with the adjacent channel and consequent dispersion of low Chl a channel water into MI. We measured the dispersive Chl $a$ flux at this location for 40 days; the results showed large tidal oscillations but net (tidally averaged) export of phytoplankton biomass from MI to the exterior channel (Figure 8c). The combination of tidally oscillating currents within a domain of spatially variable Chl a drives a dispersive transport of phytoplankton from producing habitats to consuming habitats. Tidal transports could also amplify systemwide grazing losses by exposing phytoplankton to patchily distributed Corbicula along tidal excursions (approximately $10 \mathrm{~km}$ in deep narrow Delta channels).

Thus, fast transport and fast Corbicula grazing are the key processes leading to the decorrelation between phytoplankton growth rate and biomass distribution. Phytoplankton biomass provides no information about these governing processes, so biomass alone is a weak indicator of the ecological value of aquatic habitats.

\section{Why Are Phytoplankton and Zooplankton Biomass Uncorrelated?}

We hypothesized that zooplankton biomass would covary with phytoplankton biomass because the algal food supply is commonly suboptimal for the growth of pelagic consumers across the Delta. However, producer and consumer biomass were uncorrelated (Figure 5a). We will therefore consider three processes that dampen or cloud the trophic linkage between phytoplankton and zooplankton.

Adaptive Feeding Efficiency. From a fixed, Eulerian frame of reference, the highly variable ratio $\mathrm{ZB}: \mathrm{PB}$ suggests high variability in the yield of zooplankton per unit of phytoplankton biomass and that this yield is highest at low food levels (Figure $5 \mathrm{~b}$ ). This pattern derives from the ingestion model, which is grounded in a rich history of feeding experimentation showing that particle capture is a nonlinear, asymptotic function of food density (for example, see Harris and Paffenhöfer 1976; Mullin and Brooks 1967). Although the ingestion rate of individual taxa was computed as a function of temperature, size-dependent optimal rations, and food availability, the computed ration for the zooplankton community (ZG:ZB) was strongly influenced by the asymptotic Ivlev ingestion function (Figure 5c). The index ZG:ZB shows that variability of daily ration above $\mathrm{PB}$ of approximately $300 \mathrm{mg} \mathrm{C} \mathrm{m}^{-3}\left(2.1\right.$ to $\left.2.5 \mathrm{~d}^{-1}\right)$ is much smaller than variability of the food resource PB (up to $880 \mathrm{mg} \mathrm{C} \mathrm{m}^{-3}$ ). This highly damped propagation of variability from food concentration to ingestion is a consequence of feeding mechanics and behavior that enable calanoid copepods to efficiently exploit a dilute phytoplankton suspension (minimum daily ration was $70 \%$ of biomass per day), (Figure $5 \mathrm{c}$ ) and rapidly attain a maximum ration that does not grow with further increases in food concentration. This nonlinear feeding function describes a compensatory mechanism that buffers the effect of food variability on zooplankton ingestion and production (Pace and others 1999).

Food Subsidies and Habitat Connectivity. An Eulerian reference frame misses the tidal time-scale transports of water parcels and their contained plankton across habitat gradients, so it is difficult to assess the complexities of phytoplankton-zooplankton coupling from fixed-point sampling. Transport within and between habitats can suppress the "local" trophic cascade effect by facilitating habitat food subsidies. Water and suspended particles are exchanged between habitats over the course of a tidal cycle (Monsen and others 2002), and transport can act as a mechanism for net displacement of particles (including phytoplankton) from one habitat type to another (Lucas and others 2002). Calculations of percent production consumed by zooplankton (ZG:PP) indicate that a food deficit exists in habitats deeper than about $10 \mathrm{~m}$, implying an external source of phytoplankton to sustain zooplankton nutrition in deep habitats (Figure 6a). Furthermore, the index $\mathrm{PP}_{\mathrm{Res}}$ reveals production deficits in both shallow habitats (primarily due to Corbicula grazing) and deep ones (Figure 6b). These recipient habitats may be subsidized by the net transport of food from neighboring connected donor habitats, such as southern MI, where residual production averaged $290 \mathrm{mg} \mathrm{C} \mathrm{m}^{-3} \mathrm{~d}^{-1}$.

Phytoplankton biomass may be transported across other boundaries (than the northern opening) along the perimeter of MI. Time series of Chl $a$ in MI suggest that phytoplankton biomass is rela- 

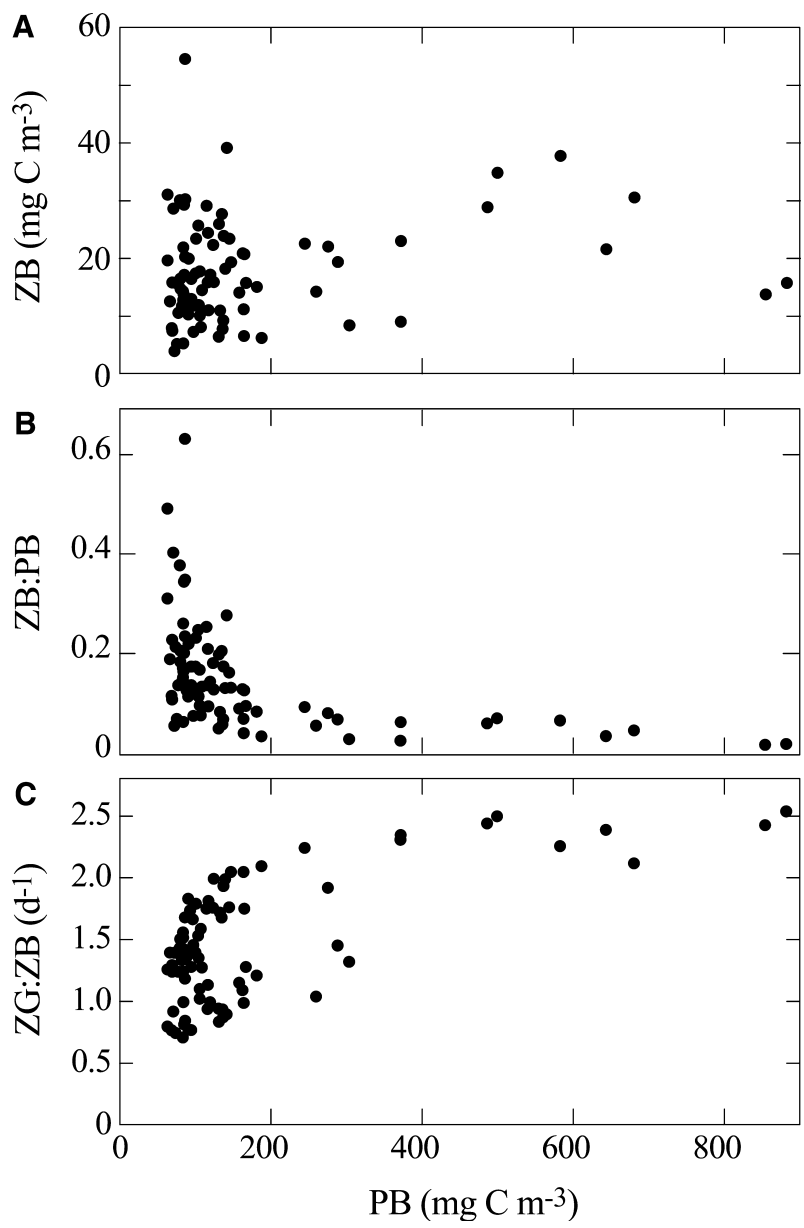

Figure 5. A Zooplankton biomass (ZB). B Potential grazing pressure (ZB:PB). C the zooplankton daily food ration $(\mathrm{ZG}: \mathrm{ZB})$ against phytoplankton biomass $(\mathrm{PB})$ from samples collected in/around MI during 2001 and FT during 2002.

tively stable over periods of days (Figure $8 \mathrm{~b}$ ), indicating that a positive value for $\mathrm{PP}_{\mathrm{Res}}$ represents production that may be exported from the habitat. We calculated total residual production for the interior of $\mathrm{MI}\left(\mathrm{PP}_{\mathrm{Res}-\mathrm{MI}}\right)$ to estimate the potential daily flux of $\mathrm{C}$ from MI. We subtracted average

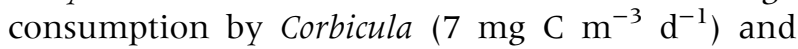
zooplankton ( $48 \mathrm{mg} \mathrm{C} \mathrm{m}^{-3} \mathrm{~d}^{-1}$ ) within MI from a total daily PP of $180 \mathrm{mg} \mathrm{C} \mathrm{m}^{-3} \mathrm{~d}^{-1}$ (calculated from the high-resolution mapping data) to arrive at a potential daily $\mathrm{C}$ export of $2,380 \mathrm{~kg} \mathrm{C} \mathrm{d}^{-1}$ (using a volume for MI of $1.9 \times 10^{7} \mathrm{~m}^{3}$, Monsen and others 2002). This export of shallow-habitat derived phytoplankton would subsidize $22-23 \mathrm{~km}^{2}$ (around five times MI's surface area) of channel habitat sparsely colonized by Corbicula (for example, M4 or M6) or about $2 \mathrm{~km}^{2}$ (only one-half of MI's surface area) of heavily colonized channel habitat with large deficits (for example, M3 and M5), (Figure 7c). Here, $\mathrm{PP}_{\text {Res-MI }}$ illustrates the potential value of a donor habitat like MI to the entire system; however, the value of such donor habitats will decrease as more habitats are colonized by Corbicula.

Fish Predation. Zooplankton dynamics can be tightly regulated by predation (Jeppesen and others 2003), so top-down processes can also explain the weak correlation between zooplankton and phytoplankton biomass. Fish predation was not measured in our study, but low values of ZB:PB (less than 0.2 ) in the majority of samples (Figure $5 \mathrm{~b}$ ) are comparable to values in lakes where high predation pressure is exerted on zooplankton by planktivores (Jeppesen and others 2003). Grimaldo and others (2004) found that ichthyoplankton abundance was higher in southern MI (where mean ZB:PB $=0.05$ ) than in the north (where mean $\mathrm{ZB}: \mathrm{PB}=0.23$ ), suggesting that zooplankton production efficiency (as biomass per unit of food resource) is influenced by spatially variable predation.

\section{Implications for Habitat Restoration Programs}

This study was designed to assess pelagic functions in a disturbed ecosystem that is now the focus of large-scale restoration. One practical value of ecosystem science can come from the application of fundamental principles to guide strategic plans for meeting management targets, such as the amplification of functional diversity or the sustainability of native species. Our collective experience in applying ecological principles to meet restoration goals is limited, so lessons from site-specific studies might be useful starting points for designing assessments of habitat functional variability in other large ecosystems. The results presented here offer three lessons that may extend beyond the SacramentoSan Joaquin Delta and could provide a basis for comparing our evolving experiences in the application of ecosystem science to management of other large aquatic ecosystems.

Performance Measures of Ecosystem Management. Other large-scale programs of ecosystem rehabilitation (Clark and Zaunbrecher 1987; Walters and others 1992) are built from frameworks of adaptive management in which the outcomes of restoration actions are followed through monitoring and then lessons are applied to refine guiding conceptual models and next-phase management actions (Holling 1978; Walters 1986; Ringold and others 1996). Our results illustrate the importance of monitoring design for measuring the performance of management actions. For example, 
A
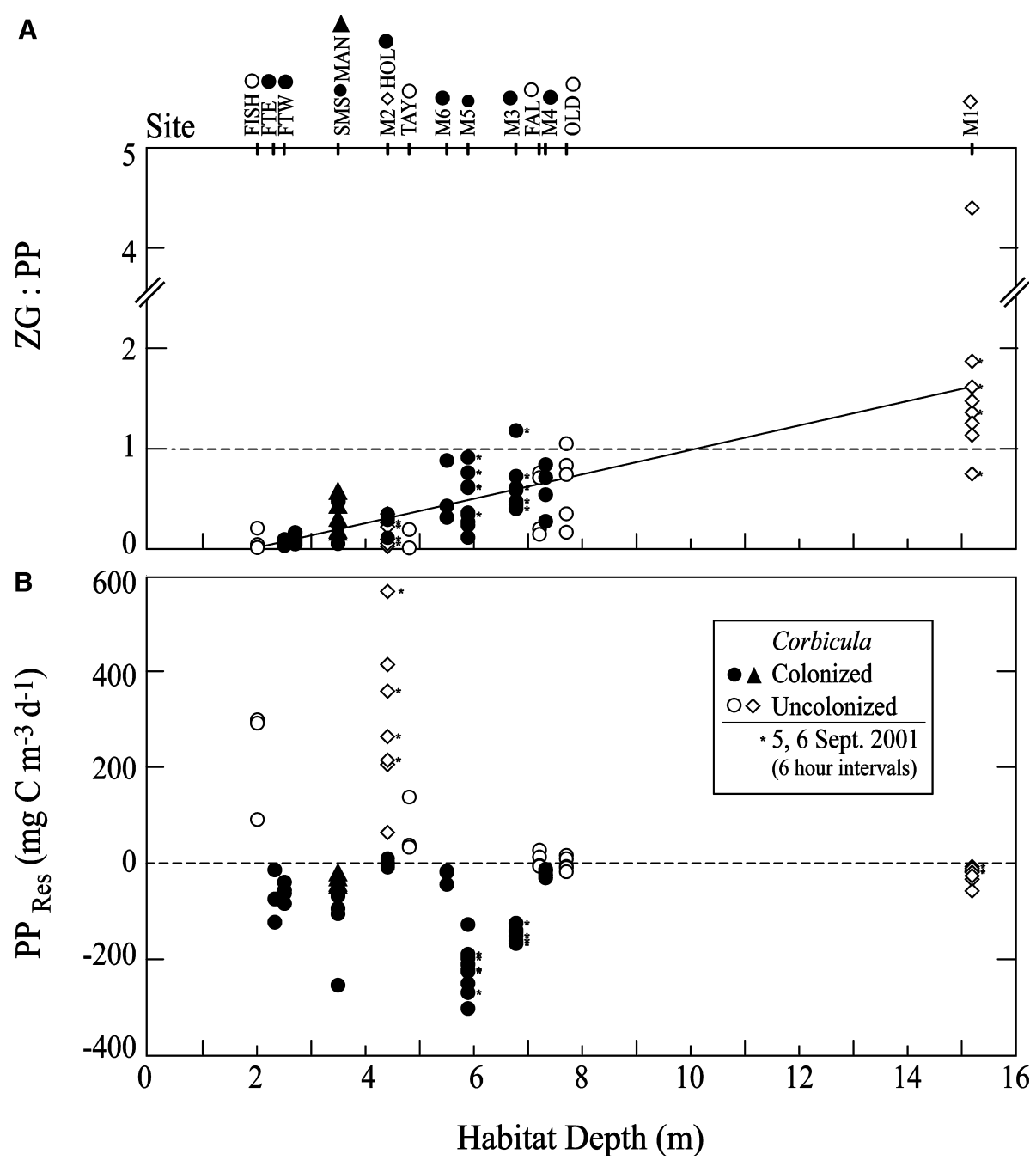

Figure 6. A The ratio of zooplankton grazing to primary production (ZG:PP). B Residual primary production ( $\left.\mathrm{PP}_{\mathrm{Res}}\right)$ versus mean habitat depth from samples collected in/around MI in 2001 and FT in 2002. Open symbols indicate stations where the invasive clam, Corbicula, was rare or absent ("uncolonized"). Filled symbols indicate stations where Corbicula was abundant ("colonized"). Asterisks next to symbols indicate samples taken every $6 \mathrm{~h}$ over $30 \mathrm{~h}$ on 5-6 September 2001. Station and corresponding symbols are detailed on the top $x$-axis. A The horizontal dashed line divides surplus and deficit habitats based on zooplankton consumption alone. The trendline represents the linear fit of ZG:PP $(y=-0.22$ $\left.+0.13 x, R^{2}=0.57\right)$ with depth. B For $\mathrm{PP}_{\mathrm{Res}}$, the horizontal dashed line separates potential donor $\left(\mathrm{PP}_{\mathrm{Res}}>0\right)$ and recipient $\left(\mathrm{PP}_{\mathrm{Res}}<\right.$ $0)$ habitats when consumption by both zooplankton and Corbicula is taken into account. if the goal is to amplify production in food webs that sustain endangered or threatened species, then the biomass of primary and secondary producers could be monitored to test the hypothesis that habitat creation leads to increased stocks of forage biota and their food supply. However, biomass alone is not a sufficient metric for interpreting the outcomes of habitat creation because it provides no information about the underlying processes of biomass change. We show here that phytoplankton biomass in a low-productivity ecosystem is only weakly related to phytoplankton growth rate across habitat gradients because other processes (transport, mixing, and consumption) contribute to biomass variability.

Success in the experimental application of adaptive management depends on monitoring to provide sufficient information for both measuring and understanding the outcomes of habitat creation, so that subsequent phases can incorporate improved mechanistic knowledge of the linkages between habitats and the functions they provide. In the absence of process measurements, indices can be derived to provide strong clues about the functional responses of manipulated ecosystems. For example, $\mathrm{ZG}: \mathrm{PP}$ and $\mathrm{PP}_{\mathrm{Res}}$ indices distinguish habitats that function as net producers or net consumers of algal biomass. Efficiency indices (ZG:ZB, ZB:PB) provide clues about why consumer and producer biomass and production are weakly correlated, even where consumers are food limited. Thoughtful design of post-ecosystem manipulation data collection and analysis might be just as important to the success of adaptive management as the design of ecosystem manipulations themselves.

Habitat Connectivity. Ecosystem restoration is guided by the principle that habitat mosaics support the diversity of functions required to sustain complex communities (Noss 1983). Our results reinforce the concept that system responses to enhanced habitat diversity are strongly set by the patterns and rates of connectivity between habitats 

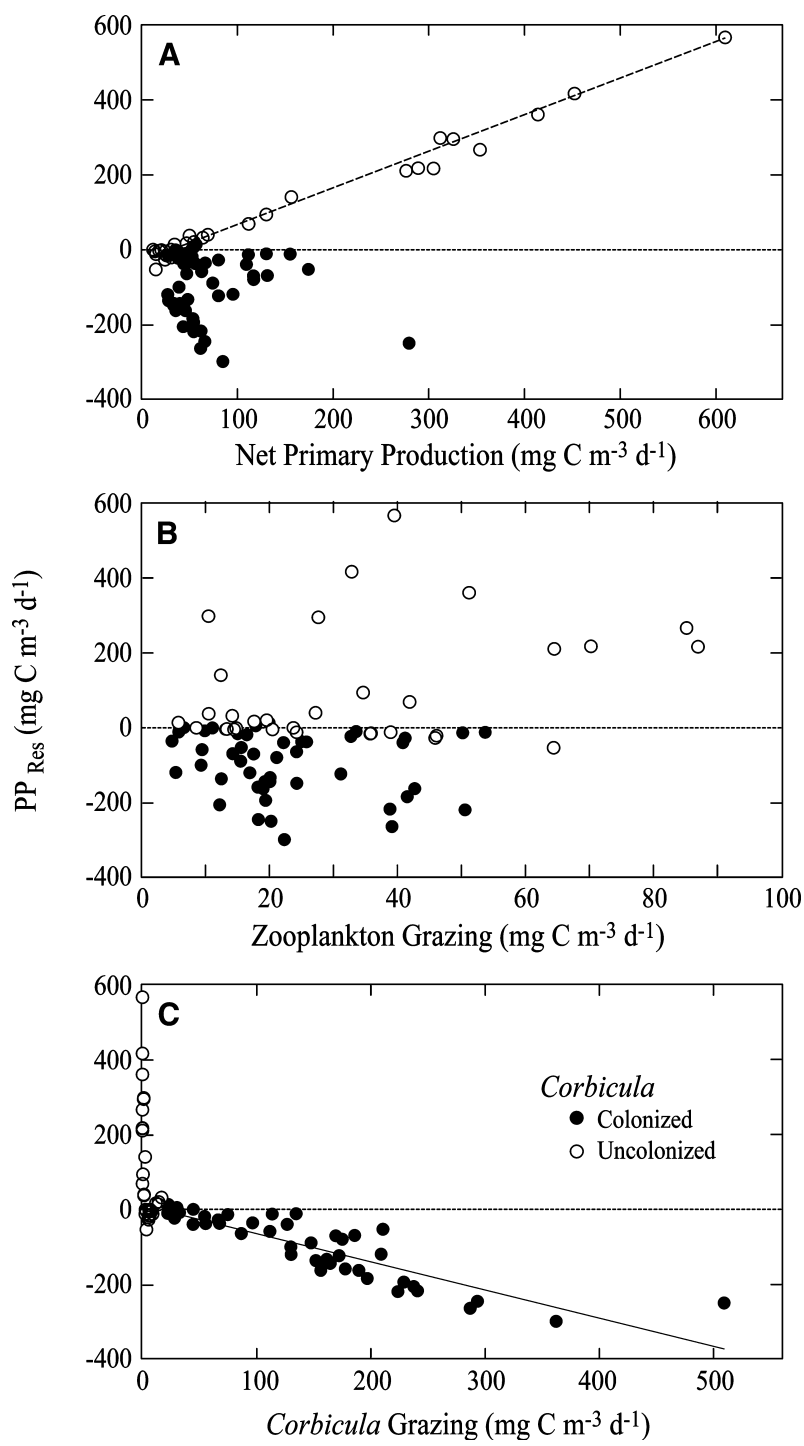

Figure 7. Residual phytoplankton production ( $\left.\mathrm{PP}_{\mathrm{Res}}\right)$ versus A net primary production (PP). B zooplankton grazing (ZG). C Corbicula grazing (CG) from samples collected during 2001 (MI) and 2002 (FT). Open circles indicate sites where Corbicula was rare or absent ("uncolonized"). Filled circles indicate sites where Corbicula was abundant ("colonized"). Trend lines represent significant correlations of $\mathbf{A} \mathrm{PP}_{\mathrm{Res}}$ at uncolonized sites with PP $\left(R^{2}=0.99, P<0.001\right)$ and $(\mathbf{C}) \mathrm{PP}_{\mathrm{Res}}$ at colonized sites with CG (inverse correlation, $R^{2}=0.77, P<0.001$ ).

(Polis and others 1997; Reiners and Driese 2001). Connectivity in aquatic systems is driven by water flows and mixing that transport materials, energy, and biota, leading to displacements of ecological values from one habitat to another. For example, we show that shallow habitats support high phytoplankton growth rates such that net primary production exceeds local zooplankton consumption, whereas light-limited deep habitats do not supply sufficient primary production to sustain local zooplankton consumption. Shallow autotrophic habitats can export algal biomass and fuel secondary production in adjacent deep heterotrophic habitats, but only if these donor and recipient habitats are physically connected.

Full assessment of the ecological values of different aquatic habitats requires measurement of hydraulic connectivity and its influence on regional-scale responses to habitat-scale processes. In complex, dynamic environments, high-frequency monitoring may be critical to quantify and understand connectivity between habitats. We see this in the tidal dispersive flux of phytoplankton biomass between northern MI and its neighboring channels: MI's contribution of phytoplankton biomass to adjacent channels results from the correlation of hourly-scale variations in current velocity and phytoplankton biomass. This flux component would not be discernable with temporally coarse (for example, weekly or monthly) measurements of flow and Chl $a$. Therefore, highfrequency monitoring may be necessary for the accurate quantification of the rates of material transport between adjacent habitats or sub habitats, especially in geometrically complex tidal environments. Such fundamental knowledge of hydrodynamic transport processes may be a general prerequisite for success in the design of management strategies and the interpretation of biotic and functional responses to habitat manipulations.

Invasive Species and Ecosystem Restoration. The global translocation of species is now recognized as a central mode of anthropogenic disturbance of ecosystems and their biological communities (Vitousek and others 1996; Cohen and Carlton 1998). We show here how alien species can exert a powerful constraint on the outcomes of management actions to rehabilitate ecosystems and their functions that sustain native species. Across a lowproductivity ecosystem where zooplankton biomass and its algal food supply have declined significantly, phytoplankton biomass is persistently low in habitats colonized by the alien clam Corbicula fluminea. On a systemwide scale, Corbicula fluminea consumes more primary production than crustacean zooplankton, and food competition between benthic and pelagic consumers is one factor in the decline of zooplankton stocks here, as in ecosystems colonized by the zebra mussel Dreissena polymorpha (Caraco and others 1997; Jack and Thorp 2000) or other bivalves such as Potamocorbula amurensis (Nichols and others 1990; Alpine and Cloern 1992). 

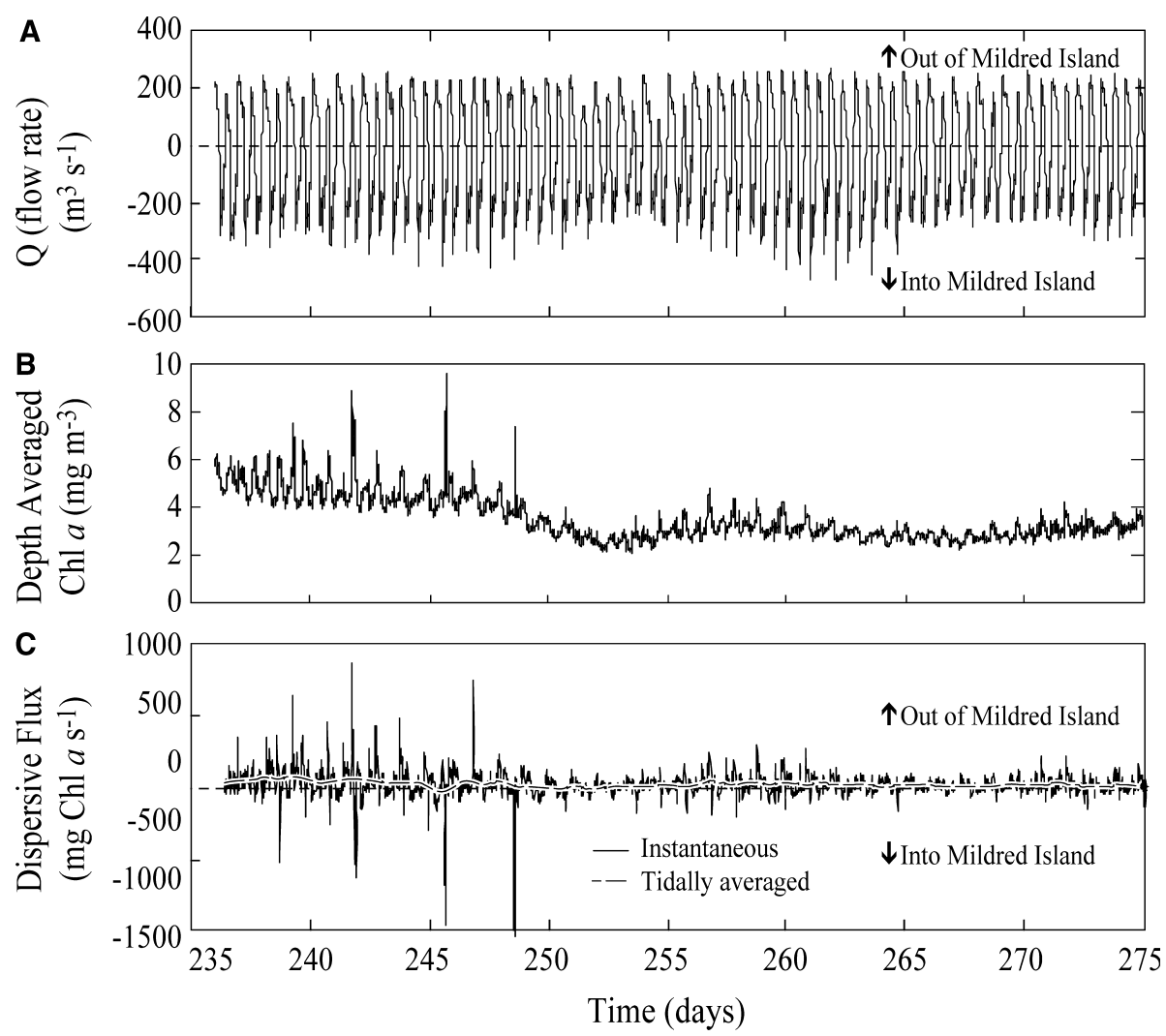

Figure 8. Time series at the northern opening of MI of $\mathbf{A}$ flow rate (Q). B depth-averaged Chlorophyll a (Chl a). C instantaneous and tidally averaged (smoothed line) dispersive flux of Chl a through the northern opening. Data were collected at 10 min intervals from 23 August to 1 October 2001. Positive values for flow rate and dispersive flux indicate flow or flux out of MI through the northern opening; negative values indicate flow or flux into MI through the northern opening. Tidally averaged dispersive flux (C, smoothed line) was generally positive (or out of MI).
The unexplained patchy distribution of Corbicula fluminea in the Sacramento-San Joaquin Delta implies high uncertainty in the outcomes of creating new aquatic habitats (Lucas and others 2002). New habitats colonized by Corbicula will function as net consumers of phytoplankton biomass and contribute little forage production in pelagic food webs. Uncolonized shallow habitats will amplify production in pelagic food webs. Although we can, to some extent, engineer habitat attributes such as bathymetry, quality of source waters, and hydrodynamic transports, we cannot control or even predict which biological communities will colonize new habitats and how those communities will evolve over time-which underscores the need for adaptive management strategies in ecosystem restoration. The alien clam Corbicula fluminea is a key species in this ecosystem, and its strong top-down control of phytoplankton biomass and production is a severe constraint on our capacity to amplify pelagic production through habitat creation. Alien species are equally compelling constraints on the recovery of native species in other large ecosystems (Sakai and others 2001). Perhaps the single most effective strategy for ecosystem rehabilitation is the preemptive strategy of aggressively curtailing the further translocation of aliens (Vitousek and others 1996).

\section{Conclusions}

The emerging era of landscape-scale environmental management provides opportunities to apply and test ecological principles to meet the goals of ecosystem rehabilitation programs. This study, which compared a small subset of ecological functions across habitat gradients in one ecosystem, illustrates three principles that may be general. First, adaptive management is a learning process, and success depends on the thoughtful design of the experimental component of post-ecosystem manipulation data collection and synthesis just as it depends on the thoughtful design of ecosystem manipulations; generic monitoring designs may not fully exploit the opportunities for learning. Second, a key to understanding and managing complex landscapes is knowledge of the patterns and rates of connectivity among habitats that drive fluxes of energy, resources, and biota and therefore determine the ecosystem-scale outcomes of habitat creation. Finally, invasive species can disrupt key processes and severely constrain the benefits of habitat restoration. The role of Corbicula fluminea as an invasive keystone species in the SacramentoSan Joaquin River Delta illustrates the need for aggressive strategies to curtail species introductions as a component of ecosystem rehabilitation. 


\section{ACKNOWLEDGEMENTS}

This work was supported by the CALFED San Francisco Bay-Delta Ecosystem Restoration Program (ERP01C07). Many thanks to our boat captains Byron Richards, Francis Parchaso, Jay Cuetara, Jon Yokomizo, Lloyd Brenn, and Eric Santos; to Andy Arnsberg, Nancy Monsen, Heather Peterson, Bill Sobczak, Michelle Shouse, Francis Parchaso, Byron Richards, Scott Waller, Kitty Triboli, Mike Demsey, Mike Simpson, Cathy Ruhl, Kurt Battenfield, Linda Cloern, and Bob Herzog for their many hours in the field and on the houseboats; to Nancy Monsen for her model output of mean depths and the Delta hypsograph; to Steve Hager and Greg Cutter for the nutrient analyses; to Jim Orsi for the zooplankton community analysis; to Dick Dufford for the phytoplankton community analysis; to Bill Sobczak for his data; to Catherine Hall for her dry weight conversions and carbon values for $E$. affinis and $P$. forbesi; and to our amazing illustrator Jeanne DiLeo. Reviews by Cindy Brown, Bill Sobczak, and two anonymous reviews greatly improved this manuscript.

\section{REFERENCES}

Alpine AE, Cloern JE. 1992. Trophic interactions and direct physical effects control phytoplankton biomass and production in an estuary. Limnol Oceanogr 37:946-55.

Andersen T, Hessen DO. 1991. Carbon, nitrogen, and phosphorus content of freshwater zooplankton. Limnol Oceanogr 36:807-14.

Atwater BF, Conard SG, Dowden JN, Hedel CW, MacDonald RL, Savage W. 1979. History, landforms, and vegetation of the estuary's tidal marshes. In: Conomos TJ, Ed. San Francisco Bay: The Urbanized Estuary. San Francisco (CA): Pacific Division, American Association for the Advancement of Science. p 347-385.

Bennett WA, Moyle PB. 1996. Where have all the fishes gone? Interactive factors producing fish declines in the SacramentoSan Joaquin Estuary. In: Hollibaugh JT, Ed. San Francisco Bay: The ecosystem. San Francisco (CA): Pacific Division, American Association for the Advancement of Science. p 51942.

Bogdan KG, Gilbert JJ. 1982. Seasonal patterns of feeding by natural populations of Keratella, Polyarthra, and Bosmina: clearance rates, selectivities, and contributions to community grazing. Limnol and Oceanogr 27:918-34.

Bottrell HH, Duncan A, Gliwicz ZM, Grygierek E, Herzig A, Hillbricht-Ilkowska A, Kurasawa H, and others. 1976. A review of some problems in zooplankton production studies. Nor J Zool 24:419-56.

Brett MT, Müller-Navarra DC, Park SK. 2000. Empirical analysis of the effect of phosphorus limitation on algal food quality for freshwater zooplankton. Limnol Oceanogr 45:1564-75.
Brown LR. 2003. Will tidal wetland restoration enhance populations of native fishes? In: Brown LR, Ed. Issues in San Francisco Estuary tidal wetlands restoration. San Francisco Estuary and Watershed Science (online serial). 1(1): Article 2.

CALFED Bay-Delta Program. 2000. CALFED Bay-Delta Program strategic plan for ecosystem restoration. Sacramento (CA): CALFED Bay-Delta Program.

CALFED Bay-Delta Program. 2001. Ecosystem restoration program draft stage 1 implementation plan. Sacramento (CA): CALFED Bay-Delta Program.

California Bay-Delta Authority. 2004. Ecosystem restoration program multi-year program plan. Sacramento (CA): CALFED Bay-Delta Program.

Caraco NF, Cole JJ, Raymond PA, Strayer DL, Pace ML, Findlay SE, Fischer DT. 1997. Zebra mussel invasion in a large, turbid river: phytoplankton response to increased grazing. Ecology 78:588-602.

Clark TW, Zaunbrecher D. 1987. The greater Yellowstone ecosystem: the ecosystem concept in natural policy and management. Renewable Resour 5(3):8-16.

Cloern JE. 1982. Does the benthos control phytoplankton biomass in south San Francisco Bay? Mar Ecol Prog Ser 9:191202.

Cloern JE, Dufford R. 2005. Phytoplankton community ecology: principles applied in San Francisco Bay. Mar Ecol Prog Ser 285:11-28.

Cloern JE, Cole BE, Wong RLJ, Alpine AE. 1985. Temporal dynamics of estuarine phytoplankton: a case study of San Francisco Bay. Hydrobiologia 129:153-76.

Cloern JE, Grenz C, Lucas LV. 1995. An empirical model of the phytoplankton chlorophyll:Carbon ratio-the conversion factor between productivity and growth rate. Limnol Oceanogr 40:1313-21.

Cohen AN, Carlton JT. 1998. Accelerating invasion rate in a highly invaded estuary. Science 279:555-8.

Crisp DJ. 1971. Energy flow measurements. In: Holme NA, McIntyre AD, Eds. Methods of the study of marine benthos. International Biological Programme handbook no. 16. Oxford (UK): Blackwell. p 197-279

Dumont H, Van de Velde I, Dumont S. 1975. The dry weight estimate of biomass in a selection of cladocera, copepoda and rotifera from the plankton, periphyton and benthos of continental waters. Oecologia (Berlin) 19:75-97.

Engelhardt KAM, Ritchie ME. 2001. Effects of macrophyte species richness on wetland ecosystem functioning and services. Nature 411:687-9.

Feyrer F, Herbold B, Matern SA, Moyle PB. 2003. Dietary shifts in a stressed fish assemblage: consequences of a bivalve invasion in the San Francisco estuary. Environ Biol Fishes 67:277-88.

Fischer HB, List EJ, Imberger J, Koh RCY, Brooks NH. 1979. Mixing in inland and coastal waters. San Diego: Academic Press, p 483.

Foe C, Knight A. 1986. A thermal energy budget for juvenile Corbicula fluminea. Am Malacol Bull Sp edn. no. 2; p 143-150.

Grimaldo LF, Miller RE, Peregrin CM, Hymanson ZP. 2004. Spatial and temporal distribution of native and alien ichthyoplankton in three habitat types of the Sacramento-San Joaquin Delta. In: Feyrer F, Brown LR, Orsi JJ, Eds. Early life history of fishes in the San Francisco Estuary and watershed. American Fisheries Society Symposium 39. p 81-96. 
Hager SW. 1994. Dissolved nutrient and suspended particulate matter data for the San Francisco Bay Estuary, California. October 1991 through November 1993. US Geological Survey Open-File Report 94-471. p 53.

Harris RP, Paffenhöfer GA. 1976. The effect of food concentration on cumulative ingestion and growth efficiency of two small marine planktonic copepods. J Mar Biol Assoc UK 56:875-88.

Holl KD, Crone EE, Schultz CB. 2003. Landscape restoration: moving from generalities to methodologies. BioScience 53:491-502.

Holling CS. 1978. Adaptive environmental assessment and management. New York: Wiley.

Jack JD, Thorp JH. 2000. Effects of the benthic suspension feeder Dreissena polymorpha on zooplankton in a large river. Fresh Biol 44:569-79.

Jacobs KL, Luoma SN, Taylor KA. 2003. CALFED: An experiment in science and decision making. Environment 45(1):3041 .

Jassby AD, Cloern JE, Cole BE. 2002. Annual primary production: patterns and mechanisms of change in a nutrient-rich tidal ecosystem. Limnol and Oceanogr 47:698-712.

Jeppesen E, Jensen JP, Jensen C, Faafeng B, Hessen DO, Søndergaard M, Lauridsen T, and others. 2003. The impact of nutrient state and lake depth on top-down control in the pelagic zone of lakes: a study of 466 lakes from the temperate zone to the arctic. Ecosystems 6:313-25.

Kimmerer WJ. 2002. Effects of freshwater flow on abundance of estuarine organisms: physical effects of trophic linkages? Mar Ecol Progr Ser 243:39-55.

Kimmerer WJ, Orsi JJ. 1996. Changes in the zooplankton of the San Francisco Bay Estuary since the introduction of the clam Potamocorbula amurensis. In: Hollibaugh JT, Ed. San Francisco Bay: the ecosystem. San Francisco (CA): Pacific Division, American Association for the Advancement of Science. p 40324.

Knowles N. 2002. Natural and management influences on freshwater inflows and salinity in the San Francisco Estuary at monthly to interannual scales. Water Resour Res 38:25-1-2511.

Lucas LV, Cloern JE, Thompson JK, Monsen NE. 2002. Functional variability of habitats within the Sacramento-San Joaquin Delta: restoration implications. Ecol Appl 12:15281547.

Monsen N. 2001. A study of subtidal transport in Suisun Bay and the Sacramento-San Joaquin Delta, California. [Dissertation]. Stanford, (CA): Stanford University. p 344.

Monsen NE, Cloern JE, Lucas LV, Monismith SG. 2002. A comment on the use of flushing time, residence time, and age as transport time scales. Limnol Oceanogr 47: $1545-53$.

Moulton TP. 1999. Biodiversity and ecosystem functioning in conservation of rivers and streams. Aquat Conservation:MarFreshw Ecosyst 9:573-8.

Müller-Navarra DC, Brett MT, Park SC, Chandra S, Ballantyne AP, Zorita E, Goldman CR. 2004. Unsaturated fatty acid content in seston and tropho-dynamic coupling in lakes. Nature 427:69-71.

Müller-Solger AB, Jassby AD, Müller-Navarra DC. 2002. Nutritional quality of food resources for zooplankton (Daphnia) in a tidal freshwater system (Sacramento-San Joaquin River Delta). Limnol Oceanogr 47:774-7.
Mullin MM, Brooks ER. 1967. Laboratory culture, growth rate, and feeding behavior of a planktonic marine copepod. Limnol Oceanogr 12:657-66.

Nichols FH, Thompson JK, Schemel LE. 1990. Remarkable invasion of San Francisco Bay (California, USA) by the Asian clam Potamocorbula amurensis. II. Displacement of a former community. Mar Ecol Progr Ser 66:95-101.

Noss RF. 1983. A regional landscape approach to maintain diversity. BioScience 33:700-6.

O'Riordan CA, Monismith SG, Koseff JR. 1995. The effect of bivalve excurrent jet dynamics on mass transfer in a benthic boundary layer. Limnol Oceanogr 40:330-44.

Orsi JJ, Mecum WL. 1996. Food limitation as the probable cause of a long-term decline in the abundance of Neomysis mercedis the opposum shrimp in the Sacramento-San Joaquin Estuary. In: Hollibaugh JT, Ed. San Francisco Bay: the ecosystem. San Francisco (CA): Pacific Division, American Association for the Advancement of Science. p 375-401.

Pace ML, Cole JJ, Carpenter SR, Kitchell JF. 1999. Trophic cascades revealed in diverse ecosystems. Trends Ecol Evol 14:483-8.

Parsons TR, Maita Y, Lalli CM. 1984. A manual of chemical and biological methods for seawater analysis. New York: Pergamon Press.

Petersen JE, Kemp MW, Bartleson R, Boynton WR, Chen C-C, Cornwell JC, Gardner RH, and others. 2003. Multiscale experiments in coastal ecology: improving realism and advancing theory. BioScience 53:1181-97.

Polis GA, Anderson WB, Holt RD. 1997. Toward an integration of landscape and food web ecology: The dynamics of spatially subsidized food webs. Annu Rev Ecol Syst 28: 289-316.

Reiners WA, Driese KL. 2001. The propogation of ecological influences through heterogeneous environmental space. BioScience 51:939-50.

Ringold PL, Alegria J, Czaplewski RL, Mulder BS, Tolle T, Burnett K. 1996. Adaptive monitoring design for ecosystem management. Ecol Appl 6:745-7.

Roe E, Eeten M. 2002. Reconciling ecosystem rehabilitation and service reliability mandates in large technical systems: findings and implications of three major US ecosystem management initiatives for managing human-dominated aquatic-terrestrial ecosystems. Ecosystems 5:509-28.

Ruhl CA, Simpson MR. 2005. Computation of discharge using the index-velocity method in tidally affected areas. US Geological Survey Scientific Investigations Report 20055004. p 34.

Sakai AK, Allendorf FW, Holt JS, Lodge DM, Molofsky J, With KA, Baughman S, and others. 2001. The population biology of invasive species. Annu Rev Ecol Syst 32:305-22.

Schemel LE, Sommer TR, Müller-Solger AB, Harrell WC. 2003. Hydrologic variability, water chemistry, and phytoplankton biomass in a large floodplain of the Sacramento River, CA, USA. Hydrobiologia 513:129-39.

Sobczak WV, Cloern JE, Jassby AD, Müller-Solger AB. 2002. Bioavailability of organic matter in a highly disturbed estuary: the role of detrital and algal resources. Proc Nat Acad Sci USA 99:8101-8105.

Sommer TR, Nobriga ML, Harrell WC, Batham W, Kimmerer WJ. 2001. Floodplain rearing of juvenile Chinook salmon: evidence of enhanced growth and survival. Can J Fish Aquat Sci 58:325-33. 
Starkweather PL. 1980. Aspects of the feeding behavior and trophic ecology of suspension-feeding rotifers. Hydrobiologia 73:63-72.

Uye S. 1982. Length-weight relationship of important zooplankton from the inland Sea of Japan. J Oceanogr Soc Jpn 38:149-58.

Vitousek PM, D'Antonio CM, Loope LL, Westbrooks R. 1996. Biological invasions as global environmental change. Am Sci $84: 468-78$
Vitousek PM, Mooney HA, Lubchenco J, Melilo JM. 1997. Human domination of the Earth's ecosystems. Science 277:494-9. Walters CJ. 1986. Adaptive management of renewable resources. New York: Macmillan.

Walters CJ, Gunderson L, Holling CS. 1992. Experimental policies for water management in the Everglades. Ecol Appl 2:189-202.

Walters RA, Heston C. 1982. Removing tidal-period variations from time-series data using low-pass digital filters. J Phys Oceanogr 12(1):112-5. 